San Jose State University

SJSU ScholarWorks

Master's Theses

Master's Theses and Graduate Research

1998

\title{
Life history of the Pacific electric ray, Torpedo Californica (Ayres), in central and southern California
}

Julie Ann Neer

San Jose State University

Follow this and additional works at: https://scholarworks.sjsu.edu/etd_theses

\section{Recommended Citation}

Neer, Julie Ann, "Life history of the Pacific electric ray, Torpedo Californica (Ayres), in central and southern California" (1998). Master's Theses. 1711.

DOI: https://doi.org/10.31979/etd.rd8d-ykmj

https://scholarworks.sjsu.edu/etd_theses/1711

This Thesis is brought to you for free and open access by the Master's Theses and Graduate Research at SJSU ScholarWorks. It has been accepted for inclusion in Master's Theses by an authorized administrator of SJSU ScholarWorks. For more information, please contact scholarworks@sjsu.edu. 


\section{INFORMATION TO USERS}

This manuscript has been reproduced from the microfilm master. UMI films the text directly from the original or copy submitted. Thus, some thesis and dissertation copies are in typewriter face, while others may be from any type of computer printer.

The quality of this reproduction is dependent upon the quality of the copy submitted. Broken or indistinct print, colored or poor quality illustrations and photographs, print bleedthrough, substandard margins, and improper alignment can adversely affect reproduction.

In the unlikely event that the author did not send UMI a complete manuscript and there are missing pages, these will be noted. Also, if unauthorized copyright material had to be removed, a note will indicate the deletion.

Oversize materials (e.g., maps, drawings, charts) are reproduced by sectioning the original, beginning at the upper left-hand comer and continuing from left to right in equal sections with small overlaps. Each original is also photographed in one exposure and is included in reduced form at the back of the book.

Photographs included in the original manuscript have been reproduced xerographically in this copy. Higher quality 6" $\times 9$ " black and white photographic prints are available for any photographs or illustrations appearing in this copy for an additional charge. Contact UMI directly to order.

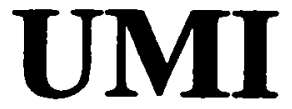

A Bell \& Howell Information Company 


\title{
LIFE HISTORY OF THE PACIFIC ELECTRIC RAY, TORPEDO CALIFORNICA (AYRES), IN CENTRAL AND SOUTHERN CALIFORNIA.
}

\author{
A Thesis Presented to \\ The Faculty of \\ Moss Landing Marine Laboratories \\ San Jose State University \\ In Partial Fulfillment \\ of the Requirements for the Degree \\ Master of Science
}

by

Julie Ann Neer

August 1998 
OuI Number: 1391534

\section{Copyright 1998 by Neer, Julle Ann}

All rights reserved.

\section{UMI Microform 1391534}

Copyright 1998, by UMI Company. All rights reserved.

This microform edition is protected against unauthorized copying under Title 17, United States Code.

\section{UMI \\ 300 North Zeeb Road \\ Ann Arbor, MI 48103}


(C) 1998

Julie Ann Veer

ALL RIGHTS RESERVED 
APPROVED FOR

MOSS LANDING MARINE LABORATORIES

Yugo. cailhet

Dr. GregordM. Cailliet
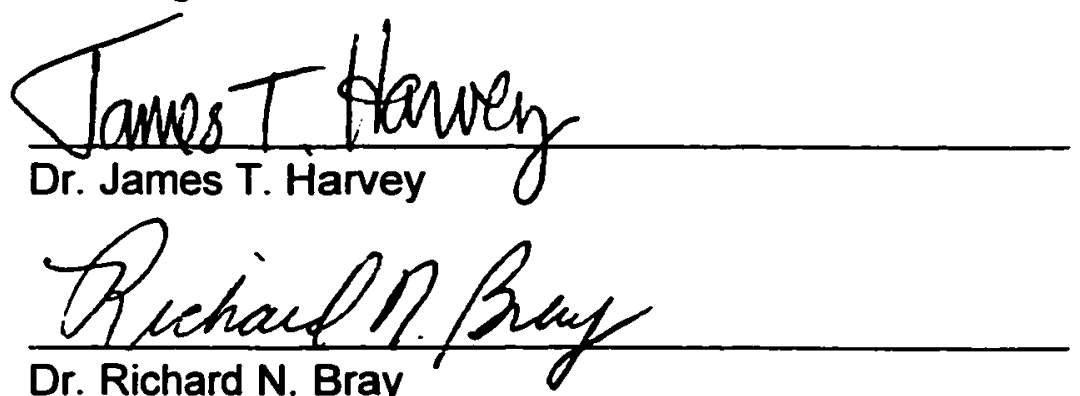

California State University - San Marcos

APPROVED FOR THE UNIVERSITY






\title{
LIFE HISTORY OF THE PACIFIC ELECTRIC RAY, TORPEDO CALIFORNICA (AYRES), IN CENTRAL AND SOUTHERN CALIFORNIA
}

\author{
Julie Ann Neer
}

Pacific electric rays were collected from central and southern California from July 1994 through January 1996 for an age and growth, reproduction, and demography study. Vertebral centra were used for ageing. Maximum age was an estimated 16 years. The von Bertalanffy growth model provided the best fit to the size-at-age estimate data, predicting an asymptotic total length of $1372 \mathrm{~mm}$ for females and $921 \mathrm{~mm}$ for males. Estimated size (and age) at sexual maturity was $600 \mathrm{~mm}$ TL (6 years) for males and $840 \mathrm{~mm}$ TL (11 years) for females, and an estimated fecundity of $\sim 17$ young per litter. Time of parturition could not to be determined. Instantaneous mortality estimates $(z)$ ranged from 0.048 to 0.277 , depending on the longevity estimates. Best demographic estimates indicate that the Pacific electric ray population is probably at equilibrium or slightly increasing with a generation time of 12.7-14.7 years, and an r of 0.07-0.13. 


\section{ACKNOWLEDGMENTS}

This thesis would have been impossible for me to complete without the help and support of numerous people. I would first like to thank my parents. My father and step mother, David and Kathy, for understanding that science does not always work on a time table, and my mother, Carol, for not totally accepting that concept. Rimmon Fay of Pacific BioMarine and Chuck Winkler of the Southern California Marine Institute for providing me with the majority of my southern California specimens. Captains Tracy Thomas and Lee Bradford for their aid in my Monterey Bay sampling. Thanks also to Korie Johnson, my main trawling partner, as well as Patty Nicely and Ron Walder for additional collection assistance, and the MLML Ichthyology Lab for all of their miscellaneous, and invaluable, help. Dan Sampson and Bruce Tanner of University of California Santa Cruz for their technical assistance with the electron microprobe. Jane Schuytema and Lynn McMasters for their help my illustrations. Ralph, Aldo, and Larry were of great help with whatever I needed. Gail Johnston and Sandy Yarbrough for helping me navigate through the SJSU system., and Sheila Baldridge and Terry Darcey for finding all of my obscure references.

Financial support for the project was provided by the Earl and Ethel Myers Oceanographic and Marine Biology Fund, the David and Lucille Packard Foundation for Marine Research, and the American Elasmobranch Society. Special thanks to the Moss Landing Marine Labs Marine Operations Department 
for providing me the shiptime necessary for my sampling. Thanks also to Mike Prince, Neddra Shutts, and Maria Kaanapu for employing me during my time here at MLML and allowing me the freedom to expand my research and personal experiences.

Extra special thanks goes to Dawn Outram who went above and beyond the call of duty helping me with whatever needed to be done. Thanks also to Enric Cortes and Dave Au for comments on the manuscript. Finally, thanks to my thesis committee without whom this work would not be what you have before you. Thanks to Jim Harvey for his editorial, design, and statistical advice. To Dick Bray for sparking my interest in ichthyology in general, and this critter in particular. And finally to Gregor Cailliet for all of his help and support throughout out my time at MLML. You have been a teacher, mentor, and friend and I will never forget all that you have given me. 


\section{TABLE OF CONTENTS}

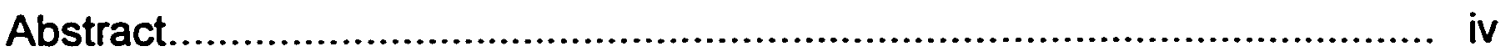

Acknowledgments ............................................................................ v

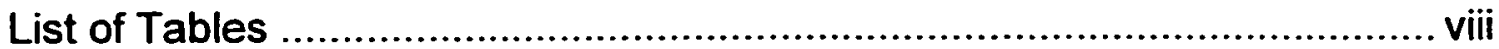

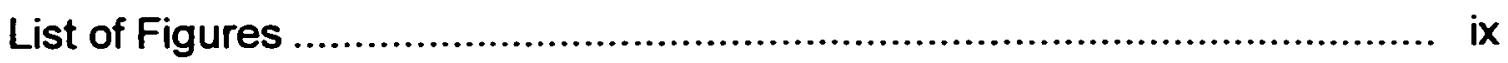

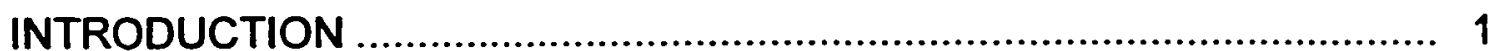

\section{METHODS}

Specimen Collection ................................................................... 5

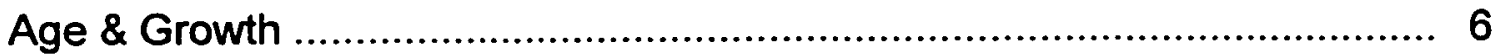

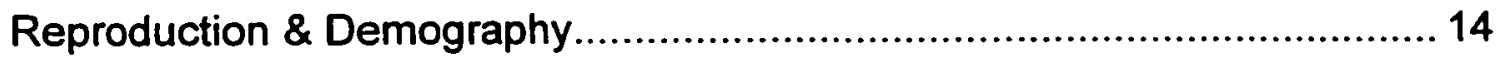

RESULTS

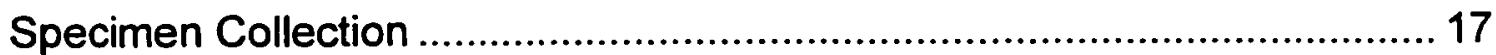

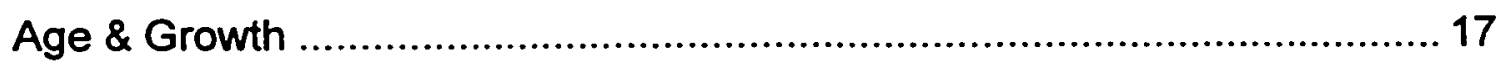



DISCUSSION

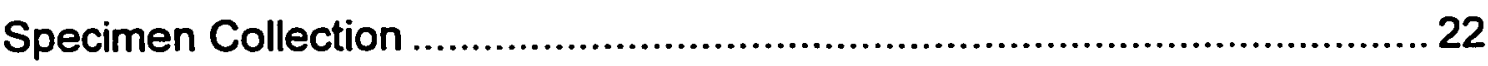

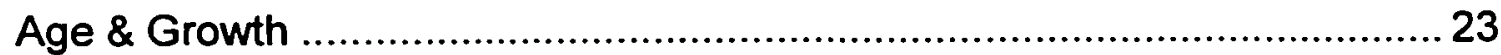

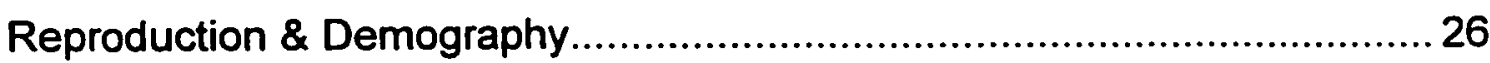

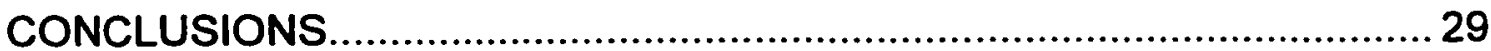

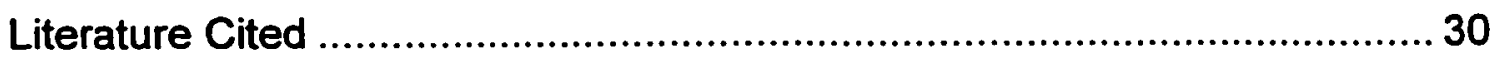




\section{LIST OF TABLES}

Table

Page

1. Summary of $r$-squared $\left(r^{\wedge} 2\right)$ and mean square error (MSE) values ....... 37

2. Fecundity information for several species of electric rays.................... 38

3. Summary of demographic parameters for four longevity and ............... 39 resulting mortality estimates obtained in this study.

4. Life table for annual reproduction.............................................................40

5. Life table for a biannual reproductive cycle ...................................... 42 


\section{LIST OF FIGURES}

Figure

1. Map of the study area ..................................................................... 43

2. Diagram of linear measurements ................................................... 44

3. Diagram of Pacific electric ray vertebrae ......................................... 45

a. Centrum diameter measurements

b. Vertebral shape with age

4. Diagram of vertebral face, with banding pattern illustrated.......................46

5. Total length frequency histogram .........................................................47

6. Total length - weight relationships.......................................................48

a. Female

b. Male

7. Plots of disc width, predorsal 1 , and predorsal 2 versus total length.........49

8. Total length and disc width versus centrum diameter.............................50

9. Precision of age determination............................................................51

10. Plot comparing age estimates for the lead microtopography and ............52 x-radiography methods

11. Example of a plot of calcium and phosphorous contentrations for one .....53 Pacific electric ray vertebra.

12. Von Bertalanffy growth curves

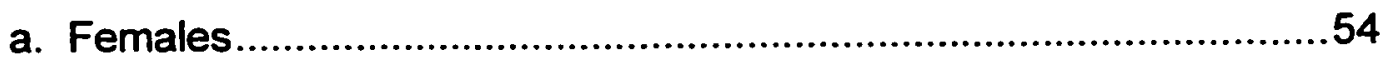



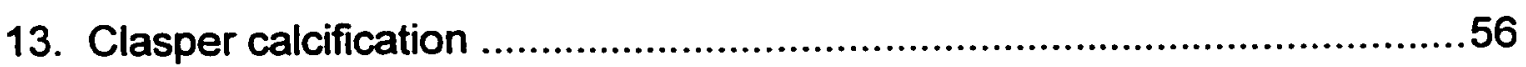



15. Maximum uterine width versus total length ............................................58



17. Maximum ovum diameter versus total length ........................................60 
Figure

Page

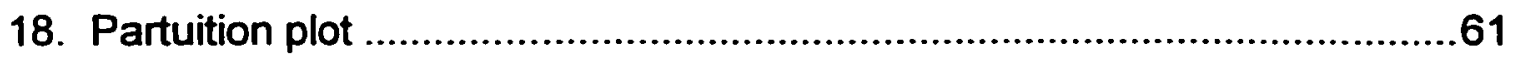

19. Simulated survivorship curves ......................................................62 


\section{INTRODUCTION}

Elasmobranchs (sharks, skates, and rays) are a diverse group of aquatic organisms occurring in many marine habitats, often occupying apex positions in ecosystems (Compagno 1990). Much of the recent research on elasmobranchs has been focused on commercially or recreationally important shark species, with coastal ray species receiving comparatively little attention (Zeiner and Wolf 1987; Martin and Cailliet 1988a, 1988b; Natanson 1993).

Electric rays (Family Torpedinidae) are cosmopolitan, aplacental viviparous elasmobranchs occurring in all major oceans of the world. Currently, there are two recognized genera containing -14 species (Nelson 1994). The Pacific electric ray, Torpedo califomica (Ayres), is the only representative of the family located off California (Eschmeyer et al. 1983). Considered common, the species ranges from Sebastian Viscaino Bay, Baja California to Queen Charlotte Islands, British Columbia, occurring at depths between 3 and $274 \mathrm{~m}$ (Miller and Lea 1972). A small fishery exists for the acquisition of biological and biomedical researcin specimens (Love 1996).

Information regarding movement patterns of the Pacific electric ray is scarce. Limited telemetry studies indicate that Pacific electric rays begin active movements after dusk and are primarily nocturnal (Bray pers. comm.).

Traditionally thought to be sluggish and passive hunters, in situ observations indicate that Pacific electric rays actively hunt for prey in the water column near 
rocky reefs and kelp beds and move rapidly in both offensive and defensive situations (Bray and Hixon 1978; Bray pers. comm.). Catch records from southern California indicate summer inshore migratory patterns, and possible segregation by sex (R. Fay pers. comm.). Segregation of animals by size also may occur along the California coast, with smaller individuals located in the northern portion of the species range (D. Bray, R. Fay, C. Lowe pers. comm.).

Whereas information exists regarding the movement patterns and diet of the Pacific electric ray, few data exist concerning its life span, age structure, or growth rate. Longevity estimates determined from vertebral centra are available for only one species of electric ray (Torpedo marmorata; Mellinger 1971), indicating that Torpedo may have traits similar to other elasmobranchs studied (slow growth, long-lived; Holden 1974). Newborn growth rates also are available but only for captive T. ocellata (Michaelson et al. 1979). Age validation was not attempted for either species.

Age determination is important for understanding population dynamics of vertebrate species. For elasmobranchs, markings on the vertebral centra are most often used for age determination and various techniques have been developed to visually enhance the banding pattern observed on vertebrae (Cailliet et al. 1986b; Cailliet 1990). Few researchers, however, have validated the temporal component of banding patterns in elasmobranchs or teleosts (Beamish and McFarlane 1983; Cailliet 1990). The annual periodicity of growth zones of only seven elasmobranch 
species have been partially validated, only two of which, Raja clavata and Raja erinacea, are batoids (Holden and Vince 1973; Cailliet 1990; Natanson 1993). Growth zones were deposited annually for these species. However, not all species studied have demonstrated annual band deposition. Natanson and Cailliet (1990) determined that growth zones in the vertebral centra of the Pacific angel shark (Squatina califomica) were not related to a temporal component but rather perhaps to somatic growth. This conclusion, along with the finding that individuals of this species displayed six to seven bands in their vertebral centra at birth, emphasized the need for validation for each species studied and that all size classes must be represented for validation to be complete (Beamish and McFarlane 1983; Cailliet et al. 1986).

A variety of methods currently exists for verifying and validating the temporal component of growth zones in calcified structures of elasmobranchs. Commonly used methods include size frequency analysis, centrum edge analysis, tag-recapture studies, and laboratory and field growth studies (Cailliet 1990). Radiometric dating was attempted for four species of elasmobranchs off California by Welden et al. (1987) but was not successful due to a violation of two assumptions of the technique. Electron microprobe analysis was promising as an additional verification technique but has rarely been used (Cailliet and Radtke 1987). 
Reproductive parameters of the Pacific electric rays are unknown. Studies of other electric ray species indicate fecundity of 4 to 18 young per female (Mellinger 1971; Michaelson et al. 1979; Villavicencio - Garayzar 1993). Mellinger (1971) and Capape (1979) reported a 2 - 3 year reproductive cycle for female T. marmorata; with males having an annual cycle. Gestation estimates for the genus range from 4 to 12 months (Quignard \& Capape 1974; Capape 1979; Abdel-Aziz 1994).

The population dynamics of the Pacific electric ray have not been investigated. Demographic anaylsis, using age-specific mortality and reproductive information, can be useful in understanding the population dynamics of a species. Its use in assessing the vulnerability of elasmobranch populations to exploitation has recently become very popular (Cortes 1994; Sminkey and Musick 1995, Au and Smith 1997).

The lack of information about the Pacific electric ray, especially regarding its basic biology, emphasizes the need for further research. To address this problem, I investigated the following hypotheses regarding the natural history of the Pacific electric ray: 1) Pacific electric rays, like other elasmobranchs, are slow growing and long-lived; 2) the use of vertebrae as an ageing structure is valid and the temporal periodicity of the banding pattern is annual; 3) male Pacific electric rays reach sexual maturity at a younger and smaller size than females; and 4) females have a low fecundity. 


\section{METHODS}

\section{Specimen Collection}

Pacific electric ray specimens were obtained between August 1994 and January 1996 off central (Monterey Bay) and southern (Los Angeles Basin) California (Figure 1).

Monterey Bay specimens were primarily collected from the 35' RN ED RICKETTS, using an 8.3-m otter trawl. Trawls were towed from 5 to 20 minutes, at an average speed of 1.5 knots. The trawls occurred at water depths of 10 to 100 $\mathrm{m}$. The body of the trawl consisted of a 3.8 centimeter $(\mathrm{cm})$ stretch mesh, and a cod end mesh of $1.3 \mathrm{~cm}$ stretch mesh. Additional Monterey Bay specimens were obtained from commercial bycatch and from additional trawling operations conducted by Moss Landing Marine Laboratories (MLML) personnel.

Southern California specimens were obtained from three sources. Rim Fay of Pacific BioMarine provided vertebrae and reproductive tracts of hand or net collected specimens. Chuck Winkler of the Southern California Marine Institute (SCMI) provided specimens after removal of the electric organs. Most of these specimens were obtained from trawls conducted by SCMI from the RN YELLOWFIN. Several specimens were provided by scientists at the Southern California Edison power plant marine lab located at King Harbor, Redondo Beach, California. These specimens were obtained from the impingement screens of the plant's biological recirculation system. 
In addition to the Pacific electric ray specimens collected during this study, I used specimens and data from the MLML Ichthyology Museum collection. All specimens were frozen after collection and stored at MLML until examination.

\section{Age and Growth}

External examinations were conducted for all specimens after thawing. When possible, rays were sexed, weighed to the nearest $0.1 \mathrm{~kg}$, and four linear measurements were recorded (Figure 2). Measurements, to the nearest millimeter (mm), were: 1) disk width (DW); 2) total length (TL; snout to tip of intact tail); 3) predorsal length 1 (PDL1; snout to origin of first dorsal fin); and 4) predorsal length 2 (PDL2; snout to insertion of second dorsal fin). Outer clasper length was also recorded for males. A subsample of specimens was measured prior to freezing and remeasured upon thawing to examine the effect freezing had on specimen size. A paired t-test was used to test for significant differences in measurements.

Vertebrae were used for ageing. A section of the vertebral column was removedjust posterior of the chondocranium to at least the insertion of the first dorsal fin. The neural arch and protective cartilage were removed, and the columns were labeled, bagged, and frozen for two weeks to six months. Vertebrae were prepared for reading following techniques outlined in Martin and Cailliet (1988a). Five to seven vertebral elements were removed from the first through $25^{\text {th }}$ vertebrae. Excess cartilage was removed using a scalpel or pointer, 
the centra placed in Clorox bleach solution (100\%) for 30 seconds to five minutes depending on size (larger vertebrae requiring more time), then placed in two changes of fresh water for 24 - 48 hours. The vertebrae were allowed to air dry and stored dry in labeled vials.

The use of vertebrae as an ageing structure was assessed. One clean vertebral centrum was selected from each specimen. Individual centrum selection was subjectively based on the lack of chips or cracks along the centrum edge. Once selected, three linear measurements of centrum diameter (CD) were recorded nearest millimeter across the centrum face using an image analyzer (Bausch and Lomb Monozoom 7 microscope attached to a Macintosh IICX equipped with Macintosh IMAGE 1.37 software; Figure 3a). The greatest of the three measurements was used for all further analyses. Centrum diameter was plotted against DW and TL to determine which measurement had a better predictive relationship (determined by $r^{2}$ value) for determining fish size from centrum size.

Banding pattern consistency throughout the column was examined. Vertebrae were removed from four locations along the vertebral column of six specimens. Centra were cleaned and the number of bands observed on the centra recorded for all positions along the vertebral column. Specimens examined were all at least $400 \mathrm{~mm}$ TL because it is assumed that variation in 
growth within an animal would most likely be observed in larger, and presumably older, individuals (Figure 3b).

Several techniques for enhancing the banding pattern on the vertebral centra were assessed. Techniques that have proven useful for other species, alizarin red staining (LaMarca 1966; Gruber and Stout 1983), silver nitrate impregnation (Stevens 1975; Cailliet et al. 1983), cedarwood oil staining (Cailliet et al. 1983), water immersion, and straight light microscopy (Cailliet et al. 1986a), did not significantly increase the readability of the banding pattern for Pacific electric rays. All of the above techniques were examined on both whole and thin-sectioned vertebrae. Techniques that had the most promise were $x$ radiography (Martin and Cailliet 1988a) and lead microtopography enhancement (Parsons 1983). The use of electron microprobe analysis also was investigated (Cailliet and Radtke 1987).

For the lead microtopography technique, one vertebra from each specimen was selected. The face of the centrum was lightly scraped with a No. 2 pencil, moving from the center of the vertebra toward the edge, to create a cone-shaped shaded area (Figure 4). The number of observed bands was recorded while viewing under an Olympus dissecting microscope using fiberoptic reflected light. 
The x-radiography technique follows Martin and Cailliet (1988a). The vertebrae were halved through the center to create two identical cones, thus eliminate confusion caused by double images on the $x$-rays. The centra were $x$-rayed using a Hewlett Packard Faxitron series X system (Model No. 43805N) with Kodak Industrex M film (ready pack M-2). After exposure, the film was processed using standard Kodak Industrex processing techniques. $X$ radiographs were viewed on a dissecting microscope with transmitted light, and the number of bands observed recorded.

Specimen age was determined by the banding pattern observed on the vertebral face. Following Cailliet et al. (1983), the term "band" refers to the larger concentric marks, composed of groups of smaller "rings" observed on the vertebral face (Figure 4). Bands, or growth zones, could be classified into two categories; more and less calcified, appearing light or dark depending on the lighting source. One band pair, comprised of one zone from each category, was assumed to represent one year. Sixty-eight samples were initially aged to establish reading criteria.

Vertebral centrum diameter at birth was estimated. All specimens less than $250 \mathrm{~mm}$ total length were assumed to be young-of-the-year (YOY). An average centrum diameter of YOY rays was determined and used as an estimate of centrum diameter at birth. This value was used as Age 0 (birth) for all band counts. 
The lead microtopography technique was used for all specimens. All vertebrae were read by the author three times, with approximately two weeks between readings. The age estimates were recorded and an index of precision (APE) and percent error (D) were calculated to assess intrareader variability (Beamish and Fournier 1981; Chang 1982). Agreement of at least two of the three readings was necessary to determine the "final" age estimate for each specimen. If all three estimates differed, an additional reading was done and a final age estimate assigned. Lead-enhanced vertebrae were additionally aged once by a second reader. These age estimates were compared with the author's final estimate and APE and D values were calculated. Percent agreement between readers also was assessed (Tanaka et al. 1990).

$X$-radiography was used for a subsample of specimens $(n=70)$. X-rays were viewed under a dissecting microscope using transmitted fiberoptic lighting. $\mathrm{X}$-rays of centra with a discernible banding pattern were read once by the author and age estimates assigned. These age estimates were compared with those obtained using the lead microtopography method using a paired t-test.

The electron microprobe analysis was conducted at the University of California - Santa Cruz using an ARISEMQ microprobe and the Probe for Windows software program. The vertebrae were embedded in epoxy resin, sectioned longitudinally through the core, and polished to a mirror finish to prevent analytical errors and diffraction of $x$-rays. The samples were then 
carbon coated to further dampen diffraction of the $x$-rays and increase electron conductance. After standardization of the probe using an apatite standard, samples were analyzed for elemental calcium and phosphorus concentrations (expressed as weight percentages). Scans were initiated at the outer edge of the vertebral arms, and proceeded toward the center in 10-micrometer increments across one half of the centrum. The beam focused on a 2-micron ${ }^{2}$ area and recorded counts for 10 seconds. The beam current was $10 \mathrm{~mA}$, operating voltage $15 \mathrm{kV}$, and absorbed current $15 \mathrm{nA}$. Scans were then compared with the band patterns and counts with those prepared using standard techniques.

Centrum edge increment analysis was attempted to determine the timing of band deposition. At least one specimen was examined from every month during the study. The outermost band was characterized as either more or less calcified and a measurement of the band width was recorded.

Validation of the temporal component of the banding pattern was attempted. Validation studies often employ the use of oxytetracycline (OTC) as an internal marker (Smith 1984; Branstetter 1987; Kusher et al. 1992; Natanson 1993). Oxytetracycline, when injected into the body, is deposited in calcifying tissues such as vertebrae. The OTC mark will fluoresce under ultraviolet light, contrasting with the surrounding unmarked region of the vertebrae. Additional bands detected outside the OTC mark represent the known time period since 
injection. Calcein, a similar internal marker, produces a more intense mark than that produced by OTC, and is visible under natural lighting conditions. It has been used as a fluorescent marker for juvenile and larval fish (Wilson et al 1987; Hales and Hurley 1991); however, its use on elasmobranchs has been limited (Gelsleichter et al. 1997).

Three laboratory growth studies using oxytetracycle (OTC) and calcein as internal markers were conducted at Moss Landing Marine Laboratories. Two 3-m diameter tanks with flow-through water systems were used to house the animals. The 3,985 $\mathrm{L}$ tanks were located outside, thereby subjecting the rays to a natural lighting regime. A sandy substrate was provided. All specimens in the validation study were obtained in otter trawls conducted in Monterey Bay.

The first validation study began 2 October 1994. Seven Pacific electric ray specimens were weighed, measured, and injected intramuscularly with $25 \mathrm{mg} / \mathrm{kg}$ OTC (Natanson and Cailliet 1990). All rays were then placed in one tank for the duration of the study. They were supplied live flatfish (Pleuronectidae, Bothidae, Cynoglossidae) and surfperch (Embiotocidae), allowing them to feed on their own schedule.

The second study began 21 July 1995. Eighteen rays were randomly allocated to one of two tanks (nine rays per tank). The rays were then allocated into one of three treatment groups: calcein, OTC, or control. AVID personal identification microchip tags (PIT) were injected subcutaneously into each animal 
to identify individuals throughout the study. Animals were weighed and measured before treatment injection. The OTC treatment group received a dosage of 25 $\mathrm{mg} / \mathrm{kg}$ (Natanson 1993). The calcein treatment group received a dosage of 5 mg/kg, following Gelsleichter et al. (1997), who recommended the lower dosage. The control group was injected with an "elasmo-ringer" solution utilized at Mote Marine Laboratory which attempts to mimic the osmolarity of serum (E. Cortes, pers comm). In addition to the food items mentioned above, these animals also were fed freshwater goldfish (Carassius auratus).

The third growth study began 17 October 1995. Nine rays were tagged with PIT tags and injected with $25 \mathrm{mg} / \mathrm{kg}$ of OTC. Weight and measurements were recorded. They were placed in one tank and fed live flatfish and surfperch. For all studies, the goal was to maintain the rays for a minimum of one year to assess the temporal deposition of the banding pattern on the vertebrae.

Growth models were fit to the age and length data using Fishparm, a non-linear curve-fitting software package (Saila et al. 1988). Gompertz, logistic, and von Bertalanffy models were fit and plotted. Mean square error (MSE) and $r^{2}$ values, provided by Fishparm, were used to determine which model had the best predictive value. Linear models also were constructed using Microsoft Excel (Microsoft Corp. 1994).

Differences in growth rates between males and females were assessed in two ways. Following Kappenman (1981), growth models were developed for the 
sexes separately and combined and examined to determine which model best described the data. Differences in the confidence intervals of parameters derived for the von Bertalanffy growth function $\left(L_{\infty}, k\right.$, and $\left.t_{0}\right)$ also were compared between sexes using a t-test (Cailliet et al. 1990).

Estimates of possible longevities were obtained through four alternative methods: 1) longevity determined by the oldest fish aged in this study, 2) longevity estimated as $5 \ln 2 / k$, representing the time it takes a fish to reach $95 \%$ of its asymptotic length (Cailliet et al. 1992; H. Mollet pers. comm.), 3) longevity estimated by extending a mean growth rate to the $L_{o o}$ predicted by the von Bertalanffy model and converting to age, and 4) longevity derived by extending the growth coefficient $k$ to the $L_{\infty}$ predicted by the von Bertalanffy model and converting to age.

\section{Reproduction and Demography}

Male and female reproductive status was examined upon dissection. Male reproductive status was based on three criteria: 1) the relationship of clasper length to total length (Babel 1967; Chen et al. 1996); 2) clasper calcification (Yano 1993); and 3) vas deferens coiling (Pratt 1979). Outer clasper length was measured for all males (Figure 2). Clasper calcification was subjectively assigned a category based on ease of clasper bending. Degree of vas deferens coiling was visually assigned to one of the following categories: straight, wavy, or coiled, or a combination of two consecutive stages (straight/wavy, wavy/coiled). 
The reproductive status of female specimens was based on three criteria: 1) number of ova (Pratt 1979), 2) diameter of ova (Pratt 1979), and 3) uterine width (Martin and Cailliet 1988b ; Timmons and Bray 1996). Fecundity was estimated using ova counts and the examination of a single pregnant female. Time of parturition in Monterey Bay was examined by plotting the size of YOY rays relative to their month of capture.

Ova and ovaries were frail and difficult to handle and examine. To alleviate this problem, the technique described by Martin and Cailliet (1988b) was used with minor modifications. Frozen organs were thawed in $70 \%$ isopropyl alcohol, then transferred to $35 \%$ isopropyl alcohol for 24 - 36 hours. This procedure imparts a tough, leathery consistency to the tissues. The organs were then drained of alcohol and refrozen. Frozen ova were then easily separated, counted, and measured. Total numbers of ova per female were obtained by counting all ova in both ovaries. Ovaries of specimens $<700 \mathrm{TL}$ were examined using microscopy. All ova present were measured along their longest axis to the nearest $0.1 \mathrm{~mm}$ using Vernier calipers.

Estimates of total instantaneous mortality $(\mathrm{z})$ were obtained using a technique introduced by Hoenig (1983). He developed a general regression equation allowing for the prediction of total mortality from maximum age of a species. The equation, derived from 134 unexploited or lightly exploited stocks of fish, mollusc, and cetaceans, has the following form: 


$$
\ln (z)=1.44+(-0.982)^{*} \ln \left(t_{\max }\right)
$$

Mortality estimates were calculated for the longevity estimates derived above.

The equation $I_{x}=\left(I_{x-1}\right)\left(e^{-z}\right)$ was used to calculate survivorship $\left(I_{x}\right)$.

Survivorship curves, using the variation in longevity and corresponding mortality, were created by plotting $I_{x}$ against fish age $(x)$ over the life span of the fish (Cailliet 1992). The various longevity and mortality estimates provided a range of probable survivorship.

A life table was constructed to estimate the demographic parameters of generation time $(G)$, net reproductive rate $\left(R_{0}\right)$, and intrinsic rate of population increase $(r)$. Several estimates of longevity and mortality $(z)$ were considered when creating the table, providing for a range of reliable estimates for each parameter. Estimates of survivorship $\left(I_{x}\right)$ and reproduction $\left(m_{x}\right)$ are necessary for the calculation of the parameters of interest. It was assumed that once a female reached sexual maturity, the potential number of female offspring $\left(m_{x}\right)$ remained constant and she reproduced annually throughout her lifetime. The fecundity estimate used in creating the life table was obtained by the examination of one pregnant female. The sex ratio at birth was assumed to be 1 to 1.

Non-annual reproduction also was considered. Demographic parameters were estimated using the most biologically realistic estimates of longevity and 
mortality and a biennial reproductive cycle. For this scenario, it was assumed that $50 \%$ of all females reproduced every other year.

\section{RESULTS}

\section{Specimen Collection}

A total of 198 specimens was obtained from central and southern California between August 1994 and January 1996. Specimens of both sexes were represented in 12 of the 18 size classes obtained; males ranged from 186 to $842 \mathrm{~mm}$ total length (TL); females from 199 to $1020 \mathrm{~mm}$ TL (Figures 1 and 5). Age and Growth

The total length-weight relationship was best described by a power curve

of the form: $y=0.00002 x^{3.0213}\left(r^{2}=0.99\right)$ for females and $y=0.00004 x^{2.8753}$ $\left(r^{2}=0.98\right)$ for males (Figure 6). Freezing did not significantly affect measurements of either disc width $\left(t_{\text {calc }}=0.312^{\prime} \mathrm{df}=19, P_{(2)}=0.758\right)$ or total length $\left(\left(t_{\text {calc }}=0.634, d f=19, P_{(2)}=0.533\right)\right.$. A very strong $\left(r^{2}=0.96-0.99\right)$ and significant ( $p<0.001$; Wilkinson et al. 1992) linear relationship existed between total length and all other measurements of body size (Figure 7).

Centrum diameter also was strongly and significantly ( $p<0.001$; Wilkinson et al 1992) correlated with total length $\left(r^{2}=0.93\right)$ and disc width $\left(r^{2}=0.98\right)$. Both measurements were predicted equally well from centrum diameter. Total 
length was selected as the primary size measurement due to its slightly higher $r^{2}$ value of 0.98 (Figure 8).

The number of bands observed at several locations along a single vertebral column did not vary within an animal. Age estimates were consistent regardless of centrum position along the column. Vertebrae may thus be obtained from any location and used for ageing.

Average centrum diameter for YOY specimens $(n=48)$ was $2.14 \pm 0.17$ $\mathrm{mm}$. This distance corresponded with an observed band in all samples examined and was used as Age 0 (birth) for all band counts.

The lead microtopography technique provided good resolution of the banding pattern and was used for all 198 specimens. Average percent error (APE) and percent error (D) among the author's first three readings were $6.5 \%$ and $4.9 \%$, respectively. Age estimates among all three readings differed by only one year in $92 \%$ of the centra. Interreader variability was also low, with an APE and $D$ of $8.5 \%$ each. The two readers agreed within one year on $81 \%$ of the centra and within two years on $93 \%$ of the centra read (Figure 9).

Age estimates determined from $\mathrm{x}$-radiography differed significantly from those obtained using the lead microtopography technique $\left(t_{\text {calc }}=4.822, \mathrm{df}=60\right.$; $P_{(2)}=0.00001$; Figure 10). The $x$-radiography technique was too variable and difficult to interpret to be used for estimating age for this species. All age estimates, therefore, were based on the lead microtopography technique. 
The electron microprobe technique was unusable as an ageing technique for this species. No discernible bands, based on calcium and phosphorous concentrations, were observed in the graphical representations of the scan data (Figure 11).

Existing data from marginal increment analysis did not provide validation of the temporal component of the observed banding pattern. Likewise, specimens in captivity did not survive the minimum of one year required for validation. The greatest duration an animal was held in captivity was 157 days. Most specimens did not feed and subsequently starved to death. Additionally, several specimens died probably because of a large influx of freshwater associated with unusually heavy rains in January 1995, and six animals were removed by an unknown assailant. Several of the oxytetracycline injected vertebrae did show evidence of OTC deposition, with almost the entire centrum glowing under ultraviolet light.

Size at age estimate plots indicated a nearly linear relationship between age and total length in males and females, and both sexes combined (Figure 12). Gompertz, logistic, and von Bertalanffy growth models fit the data equally well (Table 1). Although the Gompertz model had a slightly better fit, (with the greatest $r^{2}$ and lowest MSE) the difference between it and the von Bertalanffy growth function (VBGF) was negligible. I used the VBGF to allow for comparisons with other elasmobranch species (Hoenig and Gruber 1990). In 
addition, the $L_{o o}$ predicted by the VBGF, $1373 \mathrm{~mm}$ for females and $921 \mathrm{~mm}$ for males, closely corresponds to the maximum reported length for the Pacific electric ray, $1372 \mathrm{~mm}$ (Eschmeyer et al. 1983).

Following Kappenman (1981), it was determined that von Bertalanffy models constructed for males and females separately described the data better than one model with both sexes combined. Females reach their asymptotic length at a slightly slower rate $(k=0.07)$ than males $(k=0.13)$. The $95 \%$ confidence intervals around the predicted $\mathrm{L}_{\mathrm{oo}}$ values for males $(921 \pm 107.4 \mathrm{~mm})$ and females $(1373 \pm 288.2 \mathrm{~mm})$ did not overlap, another indication that growth in this species is best described separately for males and females, and that sexual dimorphism exists

Estimates of longevity varied widely with the method used. An estimate of 47 years was obtained using the $95 \%$ asymptotic length method and an estimate of 24 years was obtained by extending a mean growth rate to the $L_{o o}$ predicted by the von Bertalanffy model and converting to age. By extending the growth coefficient $k$ to the $L_{\infty}$ predicted by the von Bertalanffy model and converting to age, an estimate of 95 years was obtained. The longevity estimates of 47 and 95 years were determined to be biologically unrealistic. All three calculated estimates exceed the maximum age of 16 determined for specimens aged in the study. 


\section{Reproduction and Demography}

Ninety-nine male Pacific electric rays were examined for sexual maturity. All indices indicated that males mature at $600 \mathrm{~mm}$ TL (Figures 13 and 14). An abrupt change in the clasper length - TL relationship occurs at $\sim 600 \mathrm{~mm}$ TL. Eighty-three percent of males $>600 \mathrm{~mm}$ TL displayed complete coiling of the vas deferens $(n=46)$ and $87 \%$ had calcified claspers $(n=39)$. Maturity is attained at approximately six years.

Female Pacific electric rays mature at approximately $840 \mathrm{~mm}$ TL. Uterine width starts to increases rapidly at $750 \mathrm{~mm}$ TL, with a maximum observed width of $50 \mathrm{~mm}$ in a $925 \mathrm{~mm}$ TL specimen (Figure 15). The observed number of ova per female and maximum ovum diameter also indicate maturity at $840 \mathrm{~mm}$ TL (Figures 16 and 17). A $1092 \mathrm{~mm}$ TL female with $8 \mathrm{~mm}$ eggs was probably obtained shortly after giving birth. Age at female sexual maturity is approximately 11 years.

Estimates of fecundity varied with stage of female development. Both ovaries were functional, having approximately the same number of ova in each. Total number of ova ranged from $0-55$, the number increasing with increasing size of female rays (Figure 16). However, two distinct ovum size classes often were present in each ovary. A single pregnant female (1000 mm TL) was examined and contained 17 near-term embryos ( 7 females; 10 males), ranging 
from 214 to $231 \mathrm{~mm}$ total length. The fecundity estimate presented here (17) agrees reasonably well with that observed for other electric rays (Table 2).

Parturition may occur in all months. No seasonal pupping time could be determined. Young-of-the-year specimens ( $<250 \mathrm{~mm}$ total length) were obtained year-round from Monterey Bay (Figure 18).

Estimates of total instantaneous mortality $(z)$ ranged from 0.048 to 0.277 , with increasing longevity resulting in decreased mortality (Table 3). The longevity estimate of 95 years is unrealistic for this species, therefore, no corresponding survivorship curve was constructed. Survivorship curves generated using the remaining three mortality estimates most closely approximate a type III curve (Figure 19).

Using the various longevity and mortality estimates, demographic estimates of generation time (G) ranged from 12.7 to 29.8 years. Net reproductive rate $\left(R_{0}\right)$ estimates ranged from 1.4 to 104.5 for this species. Intrinsic rate of increase ( $r$ ) estimates ranged from 0.02 to 0.26 , indicating that the population is stable or increasing (Tables 3 and 4 ).

The possibility of non-annual reproduction was also examined. Using the most biologically realistic estimates of longevity and mortality (24 years, $z=$ 0.186 ), a biennial reproductive cycle was simulated. This resulted in $r=0.07$, in contrast to $r=0.13$ under the annual reproduction assumption. 


\section{DISCUSSION}

\section{Specimen Collection}

This species previously thought to segregate by size but this was not well defined. The bimodal size frequency distribution seen in Figure 5 most likely represents a sampling bias. The majority of specimens $>500 \mathrm{~mm}$ TL were obtained from commercial collectors in southern California who selectively take larger individuals for their larger electric organs. The majority of $<500 \mathrm{~mm} \mathrm{TL}$ specimens were obtained from Monterey Bay. Larger individuals are taken in . Monterey Bay as bycatch by commercial fishermen. However large rays were seldom retained because of limited holding space and fishing ground distance from port. In addition, large individuals have been observed from the Monterey Bay Aquarium Research Institute's ROV Ventana and from the DSV Delta during dives in the Monterey and surrounding submarine canyons (K.Schlining, M. Yoklavich, pers. comm.). These deepwater areas were not accessible to the sampling gear I utilized. Thus, probably no size frequency differences exist between central and southern California.

\section{Age and Growth}

Vertebrae provide a suitable structure for age determination in the Pacific electric ray. To be useful for ageing, the ageing structure must continue to grow proportionally to the size of the fish and age increments must be continually added to the structure. This was demonstrated for the Pacific electric ray by 
examining the centrum diameter - total length relationship (Figure 8). Age increments appear to be continually added, with no evidence of reabsorbtion, based on size at age plots (Figure 12). Additionally, vertebrae may be useful for determining age estimates for this species because the position of the centrum along the vertebral column did not affect the age estimate. This factor is important when obtaining samples from unknown origin (such as fishermen or collectors).

Pacific electric ray vertebrae are very thin, fragile, deeply-coned structures. They are poorly calcified when compared to most other elasmobranch species previously studied. Most commonly used techniques for enhancing the vertebral banding pattern failed to be useful for this species. Of the three techniques that were most promising (lead microtopography, $x$ radiography, and electron microprobe analysis), only one proved useful, lead microtopography. A new copper substitution technique under development did not enhance the banding pattern, although it has worked well with other test species (J. Gelsleichter pers. comm.).

The poor calcification may explain the difficulty of using the x-radiography technique. The $\mathrm{x}$-rays where often washed out, displaying either poorly defined bands or no banding pattern at all. It is possible that this technique could work if the vertebrae were x-rayed on a suitably sensitive machine. 
The electron microprobe technique might not be useful for ageing elasmobranchs. Although Cailliet and Radtke (1987) found it helpful in enhancing the banding pattern for the gray reef shark (Carcharhinus amblyrhynchos) and the common thresher shark (Alopias vulpinus), I was unable to gain any ageing information for this species. The technique also failed to produce useful information for the Australian sharpnose shark, Rhizoprionodon taylori (C. Simpfendorfer pers. comm.).

Pacific electric rays may not exceed approximately 16 years of age, the age estimate of the largest specimen obtained in this study. The largest individual was $1020 \mathrm{~mm}$ in total length, smaller than the maximum reported length of $1372 \mathrm{~mm}$ for females of the species (Eschmeyer et al. 1983). However, the asymptotic length of $1373 \mathrm{~mm}$ for females predicted by the von Bertalanffy growth model was consistent with the scientific literature and indicated that Pacific electric rays may reach approximately 24 years of age.

An estimated longevity of 24 years is comparable to that of other species in this family. Female Torpedo marmorata age estimates may have a lifespan of approximately 20 years and males may live to approximately 13 (Mellinger 1971). The lesser electric ray, Narcine brasiliensis may exceed 11 years for males and 15 years for females (Villavicencio - Garayzar and Cailliet, pers. comm.). The bat ray (Myliobatis califomica; Myliobatididae), a similar elasmobranch occupying the same range, has a longevity of approximately 23 
years (Martin and Cailliet 1988a). None of the above age estimates have been validated.

All estimates of longevity depend upon the accuracy of age estimates used to derive them. Unfortunately, age estimates for the Pacific electric ray could not be validated. Despite numerous attempts to keep these animals in captivity, and that other species such as the marbled ( $T$. marmorata) and spotted ( $T$. ocellata) electric ray have been successfully raised (Belbenoit 1979; Michaelson et al. 1979; J. O'Sullivan, Monterey Bay Aquarium, pers. comm.), we were unable to maintain Pacific electric rays in captivity for growth validation studies. Tag and recapture methods require sufficent specimens for release and tag returns. This was not the case in this study as all captured rays were necessary for an adequate sample size for age estimation. Centrum edge analysis was attempted, as specimens were captured from every month, however, most specimens were young-of-the-year and demonstrated no distinctive seasonal edge characteristics.

Despite the lack of validation of my age estimates, I feel confident in my conclusions for several reasons. The sample size used in this study $(n=198)$ is large for elasmobranchs, the specimens covered almost the entire size range of the species, and both sexes were well represented (Figure 5). In addition, the low APE and D values provide some verification of the age estimates (Figure 9) 
and the von Bertalanffy growth model parameter estimates seem sensible when compared to other elasmobranch species (Figure 12; Cortes and Parsons 1996). Reproduction and Demography

The onset of male sexual maturity occurs at approximately 6 years of age or $65 \%$ of the predicted total length obtained by males. Males of the marbled electric ray, T. marmorata, reach sexual maturity at 5 years (Mellinger 1971). The use of an internal reproductive measure (vas deferens coiling) in addition to the commonly used total length-clasper length relationship strengthens the conclusion that male Pacific electric rays reach maturity at approximately 600 $\mathrm{mm}$ total length.

Female Pacific electric rays reach sexual maturity at approximately $62 \%$ of their reported maximum size or 11 years of age. This estimate agrees with that for the marbled electric ray, T. marmorata, which reaches maturity at 10 to 15 years; $55-68 \%$ of its maximum size (Mellinger 1971; Capape 1979; AbdelAziz 1994). The estimate for the spotted electric ray, T. ocellata is slightly lower at $41-53 \%$ of maximum total length (Quignard and Capape 1974).

The Pacific electric ray is similar to other elasmobranchs in having low fecundity (Natanson 1984; Timmons and Bray 1997). The fecundity estimate reported here, 17 young per female, is the highest reported for the family (Table 2). Although this estimate is based on only one pregnant female, it is realistic when fecundity estimates for each species are examined in relation to their 
maximum lengths (Table 2). An increase in fecundity with body size has been observed for several species of sharks (Smith and Abramson 1990).

Mortality estimates ( $z$ ) were dependent on the longevity estimates used to generate them. The values ranged from approximately 0.048 to 0.277 . All estimates fit within the range published by Hoenig (1983); however, the lowest two estimates $(0.048$ and 0.096$)$ fall at the extreme end of the range presented. The mortality estimates of 0.277 and 0.186 seem most biologically realistic for the Pacific electric ray. The sampling biases discussed above precluded me . from plotting a meaningful catch curve. Additional samples in the middle size classes would be helpful to redefine and possibly verify the mortality estimates presented here.

The demographic parameters calculated using the two most biologically realistic estimates of longevity (16 and 24$)$ and mortality fit well within the range of values presented for other elasmobranch species (Cortes 1995). The case of the Pacific angel shark, Squatina califomica, is especially interesting (Cailliet et al. 1992). The parameter estimates derived for $S$. californica $\left(R_{0}=2.25 ; G=\right.$ 14.5; and $r=0.056)$ and the Pacific electric ray $\left(R_{0}=5.99 ; G=14.7\right.$; and $r=$ 0.13), are similar. Both species co-occur over much of their range and have similar behavioral patterns (i.e. ambush predators during the day). The greatest values of $r(0.22$ and 0.26$)$ generated for the Pacific electric ray, indicating that the population is increasing rapidly, seemed unrealistic. This is not surprising as 
the longevity estimates used to calculate them (0.096 and 0.048$)$ also were unrealistic.

Simulating a biennial reproductive cycle did not greatly affect the demographic parameter estimates, mainly influencing $r$ and $R_{o}$ (Table 5). Although direct evidence of such a cycle was not discovered during this study, $T$. marmorata have a 2 - 3 year breeding cycle (Mellinger 1971; Capape 1979). The possibility of a non-annual cycle might also explain the small numbers of females collected with mature ova and the capture of YOY individuals year round.

\section{CONCULSIONS}

Pacific electric rays appear to be similar to other elasmobranchs in being long-lived, having a low fecundity, and having a late age at sexual maturity. Demographic estimates indicate that the central and southern California population may be at equilibrium or slightly increasing. More detailed information regarding parturition season, reproductive cycles, and natural mortality is needed to refine the estimates presented here. Validation of my age estimates also needs to be accomplished. 


\section{LITERATURE CITED}

Abdel-Aziz, S.H. 1994. Observations on the biology of the common torpedo (Torpedo torpedo, Linnaeus, 1758) and marbled electric ray (Torpedo marmorata, Risso, 1810) from Egyptian Mediterranean waters. Aust. J. Mar. freshwater Res. 45:693-704.

Applegate, S.P. 1967. a survey of shark hard parts. IN: Sharks, Skates, and Rays P.W. Gilbert, R. Mathewson, D. Rall, eds) John Hopkins Press, Maryland.

Au, D.W. and S.E. Smith. 1997. A demographic method with population density compensation for estimating productivity and yield per recuit of the leopard shark (Trakis semifasciata). Can J. Fish. Aquat. Sci. 54:415-420.

Babel, J.S. 1967. Reproduction, life history and ecology of the round stingray Urolophus haleri Cooper. Cal Fish and Game Bul. 137. 104 pp.

Beamish, R.J. and D.A. Fournier. 1981. A method of comparing the precision of a set of age determinations. Can. J. Fish. Aquat. Sci. 38:982-983.

Beamish, R.J. and G.A. McFarlane. 1983. The forgotten requirement for age validation in fisheries biology. Trans. Amer. Fish. Soc. 112(6):735-743.

Belbenoit, P. 1979. Electric organ discharge of Torpedo (Pisces): basic pattern and ontogenetic changes. J. Physiol. Paris 75:435-441.

Branstetter, S. 1987. Age and growth validation of newborn sharks held in laboratory aquaria, with comments on the life history of the Atlantic sharpnose shark, Rhizoprionodon terraenovae. Copeia 1987(2):291-300.

Bray, R.N. and M.A. Hixon. 1978. Night-shocker: Predatory behavior of the Pacific electric ray (Torpedo californica). Science 200:333-334.

Cailliet, G.M. 1990. Elasmobranch age determination and verification: An updated review. IN Elasmobranchs as Living Resources: Advances in the Biology, Ecology, Systematics, and the Status of the Fisheries (H.L. Pratt, S.H. Gruber, and T. Taniuchi, eds.). NOAA Tech. Rep. 90 (1990) NMFS.

Cailliet, G.M. and R.L. Radtke. 1987. A progress report on the electron microprobe analysis technique for age determination and verification in elasmobranchs. IN The age and growth of fish (R.C. Summerfelt and G.E. Hall, eds. ). p. 359-369. lowa State University Press, lowa. 
Cailliet, G.M., M.S. Love, and A.W. Ebeling. 1986a. Fishes: a field and laboratory manual on their structure, identification, and natural history. Wadsworth Publishing. Belmont, California. pp144-157.

Cailliet, G.M., R.L. Radtke, and B.A. Welden. 1986b. Elasmobranch age determination and verification: A review. IN Indo-Pacific Fish Biology: Proceedings of the Second International Conference on Indo-Pacific Fishes (T. Uyeno, R. Arai, T. Taniuchi, and K. Matsuura, eds). p.345-360. Ichthyol. Soc. Jpn. Tokyo.

Cailliet, G.M., K.G. Yudin, S. Tanaka, and T. Taniuchi. 1990. Growth characteristics of two populations of Mustelus manazo from Japan based upon cross-readings of vertebral bands. IN Elasmobranchs as Living Resources: Advances in the Biology, Ecology, Systematics, and the Status of the Fisheries (H.L. Pratt, S.H. Gruber, and T. Taniuchi, eds.). p. 167-176. NOAA Tech. Rep. 90 (1990) NMFS.

Cailliet, G.M., L.K. Martin, D. Kusher, P. Wolf, and B.A. Welden. 1983. Techniques for enhancing vertebral bands in age estimation of California elasmobranchs. IN Proceedings of the International Workshop on Age Determination of Oceanic Pelagic Fishes: Tunas, Billfishes, and Sharks. (E.D. Prince and L.M. Pulos, eds.) p.157-165. US Dept. of Commer., NOAA Tech. Rep. NMFS 8.

Cailliet, G.M., H.F. Mollet, G.G. Pittenger, D. Bedford, and L.J. Natanson. 1992. Growth and demography of the Pacific angel shark (Squatina californica), based upon tag returns off California. Aust. J. Mar. Freshwater Res. 43:1313-1330.

Capape, C. 1979. La torpille marbree, Torpedo marmorata Risso, 1810 (Pisces, Rajiformes) des cotes tunisiennes: nouvelles donnees sur l'ecologie et la biologie de la reproduction de l'espece, avec une comparaison entre les populations mediterraneennes et atlantiques. Annales de Sciences Naturelles, Zoologie, Paris. 1:79-97.

Casey, J.G., H.L. Pratt Jr., and C.E. Stillwell. 1985. Age and growth of the sandbar shark (Carcharhinus plumbeus) from the Western North Atlantic. Can. J. Fish. Aquat. Sci. 42:963-975.

Chang, W.Y.B. 1982. A statistical method for evaluating the reproducibility of age determination. Can. J. Fish. Aquat. Sci. 39:1208-1210.

Chen, C.-T., Y.-Y. Liao, and S.J. Joung. 1996. Reproduction of the blacktip sawtail catshark, Galeus sauteri, in the waters off northeastern Taiwan. Ichthyol. Res. 43(3):231-237. 
Chilton, D.E. and R.J. Beamish. 1982. Age determination methods for fishes studied by the groundfish program at the Pacific Biological Station.Can. Soc. Publ. Fish. Aquat. Sci. no.60. 102 pp.

Compagno, L.J.V. 1990. Alternative life-history styles of cartilaginous fishes in time and space. Environ. Biol. Fish. 28:33-75.

Cortes, E. 1995. Demographic analysis of the Atlantic sharpnose shark, Rhizoprionodon terraenovae, in the Gulf of Mexico. Fish. Bull. 93:57-66.

Cortes, E. and G.R. Parsons. 1996. Comparative demography of two populations of the bonnethead shark (Sphynra tiburo). Can. J. Fish. Aquat. Sci. 53(4):709-718.

Eschmeyer, W.N., E.S. Hearld, and H. Hammann. 1983. A field guide to Pacific coast fishes of North America. Houghton Mifflin Company, Boston. 338 . pp.

Gruber, S. H. and R.G. Stout. 1983. Biological materials for the study of age and growth in the tropical marine elasmobranch, the lemon shark, Negaprion brevirostris (Poey). IN Proceedings of the International Workshop on Age Determination of Oceanic Pelagic Fishes: Tunas, Billfishes, and Sharks. (E.D. Prince and L.M. Pulos, eds.) p.193-205. US Dept. of Commer., NOAA Tech. Rep. NMFS 8.

Gelsleichter, J., E. Cortes, C.A. Manire, R.E. Hueter, and J.A. Musick. 1997. Evaluation of toxicity and effectiveness of oxytetracycline and calcein as chemical markers in elasmobranch fishes. Submitted to Trans. Amer. Fish. Soc.

Hales, L.S. Jr., and D.H. Hurley. 1991. Validation of daily increment formation in the otoliths of juvenile silver perch, Bairdiella chrysoura. Estuaries. 14(2):199-206.

Haskell, W.L. 1949. An investigation of the possibility of determining the age of sharks through annuli as shown in cross section of vertebrae. Ann. Rep. Ma. Lab., Tex. Game Fish Oyster Comm., Fiscal year 1948-1949:212217.

Hoenig, J.M. 1983. Empirical use of longevity data to estimate mortality rates. Fish Bull. 82(1):898-903.

Hoenig, J.M. and S.H. Gruber. 1990. Life-history patterns in the elasmobranch: implications for fisheries management. IN Elasmobranchs as Living Resources: Advances in the Biology, Ecology, Systematics, and the 
Status of the Fisheries (H.L. Pratt, S.H. Gruber, and T. Taniuchi, eds.). p. 1 - 16 NOAA Tech. Rep. 90 (1990) NMFS.

Holden, M.J. 1974. Problems in the rational exploitation of elasmobranch populations and some suggested solutions. IN Sea fisheries research (F.R. Harden-Jones, ed.), p. 117-137. John Wiley and Sons, New York.

Holden, M.J. and M.R. Vince. 1973. Age validation studies on the centra of Raja clavata using tetracycline. J. Cons. Int. Explor. Mar. 35(1):13-17.

Ishiyama, R. 1951. Studies on the rays and skates belonging to the family Rajidae, found in Japan and adjacent regions. 2. On the age determination of the black-skate Raja fusca Garmen (Preliminary report). Bull. Jap. Soc. Sci. Fish. 16(2):112-118.

Kappenman, R.F. 1981. A method for growth curve comparisons. Fish. Bull. 79(1):95-101.

Kusher, D.I., S.E. Smith, and G. M. Cailliet 1992. Validated age and growth of the leopard shark, Triakis semifasciata, with comments on reproduction. Environ. Biol. Fish. 35:187-203.

LaMarca, M.J. 1966. A simple technique demonstrating calcified annuli in the vertebrae of large elasmobranchs. Copeia 2:351-352.

Love, R.M. 1996. Probably more than you want to know about the fishes of the Pacific coast. 2nd edition. Really Big Press, Santa Barbara. 381pp.

Lowe, C.G., R.N. Bray, and D.R. Nelson. 1995. Feeding and associated electrical behavior of the Pacific electric ray Torpedo califormica in the field. Marine Biology 122(1):

Martin, L.K. and G.M. Cailliet. 1988a. Age and growth determination of the bat ray, Myliobatis califormica Gill, in central California. Copeia 1988(3):762773.

Martin, L.K. and G.M. Cailliet. 1988b. Aspects of the reproduction of the bat ray Myliobatis californica, in central California. Copeia 1988(3):754-762.

McFarlane, G.A. and R.J. Beamish. 1987. Validation of the dorsal spine method of age determination for spiny dogfish. Pages 287-300. IN The Age and Growth of Fish (R,C. Summerfelt and G.E. Hall, eds). lowa State Univ. Press, Ames. 
Mellinger, J. 1971. Croissance et reproduction de la torpille (Torpedo marmorata) I. Introduction, ecologie, crossance generale et dimorphisme sexual, cycle, fecundite. Bull. Biol. Fr. Belg. 105:165-218.

Michaelson, D.M., D. Sternberg, and L. Fishelson. 1979. Observations on feeding, growth, and electric discharge of newborn Torpedo ocellata (chondrichthyes, batoidei). J. Fish. Biol. 15:159-163.

Microsoft Corporation. Microsoft Excel [computer program]. Version 5.0. 1994.

Miller, D.J. and R.N. Lea. 1972. Guide to the coastal marine fishes of California. California Fish and Game Fish. Bull. 157. pp.249.

Monaghan, J.P. Jr. 1993. Comparison of calcein and tetracycline as chemical markers in summer flounder. Trans. Amer. Fish. Soc. 122:298-301.

Natanson, L. J. 1984. Aspects of the age, growth, and reproduction of the Pacific angel shark, Squatina californica, off Santa Barbara, California. Unpubl. M.A. thesis, San Jose State University, Moss Landing Marine Laboratories. 71pp.

Natanson, L.J. 1993. Effect of temperature on band deposition in the little skate, Raja erinacea. Copeia 1993(1):199-206.

Natanson, L.J. and G.M. Cailliet. 1990. Vertebral growth zone deposition in Pacific angel sharks. Copeia 1990(4):1133-1145.

Nelson, J.S. 1994. Fishes of the World 3rd Edition. John Wiley and Sons, Inc. New York. 600 pages

Parsons, G.R. 1983. An examination of the vertebral rings of the Atlantic sharpnose shark, Rhizoprionodon terraenovae. Northeast Gulf Science 6(1):63-66.

Pratt, H.L. Jr. 1979. Reproduction in the blue shark, Prionace glauca. Fish Bull. 77(2):445-470.

Pratt, H.L. Jr., and J.G. Casey. 1983. Age and growth of the shortfin mako, Isurus oxyrinchus, using four four methods. Can. J. Fish. Aquat. Sci. 40:1944-1957.

Quignard, J.P. and C. Capape. 1974. Recherches sur la biologie d'un selacien du golfe de Tunis, Torpedo torpedo Linne, 1758. Bull. de l'Institut National Scientifque et Technique d;Oceanographie et de Peche de Salammbo. 3(1-4):99-129. 
Saila, S.B., C.W. Recksiek, and M.H. Prager. 1988. Basic Fishery Science Programs: A compendium of microcomputer programs and a manual of operation. Elsevier Science Publishers, B.V. Amsterdam.

Sminkey, T.R. and J.A. Musick. 1995. Age and growth of the sandbar shark, Carcharhinus plumbeus, before and after population depletion. Copeia. 1995(4):871-883.

Smith, S.E. 1984. Timing of vertebral-band deposition in tetracycline injected leopard sharks. Trans. Amer. fish. Soc. 113:308-313.

Smith, S.E. and N.J. Abramson. 1990. Leopard shark Triakis semifasciata distribution, mortality rate, yield, and stock replenishment estimates on a tagging study in San Francisco Bay. Fish. Bull. 88:371-381.

Stevens, J.D. 1975. Vertebral rings as a means of age determination in the blue shark (Prionace glauca L.). J. Mar. Biol. Assoc. U.K. 55:657-665.

Stevenson, D.K. and S.E. Campana (eds). 1992. Otolith microstructure examination and analysis. Can. Spec. Publ. Fish. Aquat. Sci. 117:126 p.

Tanaka, S., G.M. Cailliet, and K.G. Yudin. 1990. Differences in growth of the blue shark, Prionace glauca: technique or population? IN Elasmobranchs as Living Resources: Advances in the Biology, Ecology, Systematics, and the Status of the Fisheries (H.L. Pratt, S.H. Gruber, and T. Taniuchi, eds.). p. 177-187. NOAA Tech. Rep. 90 (1990) NMFS.

Timmons, M. and R.N. Bray. 1997. Age, growth, and sexual maturity of shovelnose guitarfish, Rhinobatos productus (Ayres). Fish. Bull. 95:349359.

Villavicencio-Garayzar, C.J. 1993. Observaciones sobre la biologia reproductiva de Narcine brasiliensis (Olfers) (Pisces: Narcinidae), en Bajia Almejas, B.C.S., Mexico. Rev. Inv. Cient. 4(1):95-99.

Welden, B.A., G.M. Cailliet, and A.R. Flegal. 1987. Comparison of radiometric with vertebral band age estimates in four California elasmobranchs. IN The Age and Growth of Fish (R.C. Summerfelt and G.E. Hall, eds.).

Wilkinson, L., m.A. Hill, P. Howe, and S. Miceli. 1992. Systat for Windows, Version 5 Edition. Systat Inc., Evanston, Illinois.

Wilson, C.A., D.W. Beckman, and J.M. Dean. 1987. Calcein as a flourscent marker of otoliths of larval and juvenile fish. Trans. Amer. Fish. Soc. 116668-670. 
Yano, K. 1993. Reproductive biology of the slender smoothhound, Gollum attenuatus, collected from New Zealand waters. Environ. Biol. Fish. 38:59-71.

Zeiner, S.J. and P. Wolf. 1987. Growth characteristics and estimates of age at maturity of two species of skates (Raja binoculata and Raja hina) from Monterey Bay, California. IN Conservation of Elasmobranchs (S. Branstetter, ed.) p. 87-99. NOAA Tech. Rep. NMFS 115. 


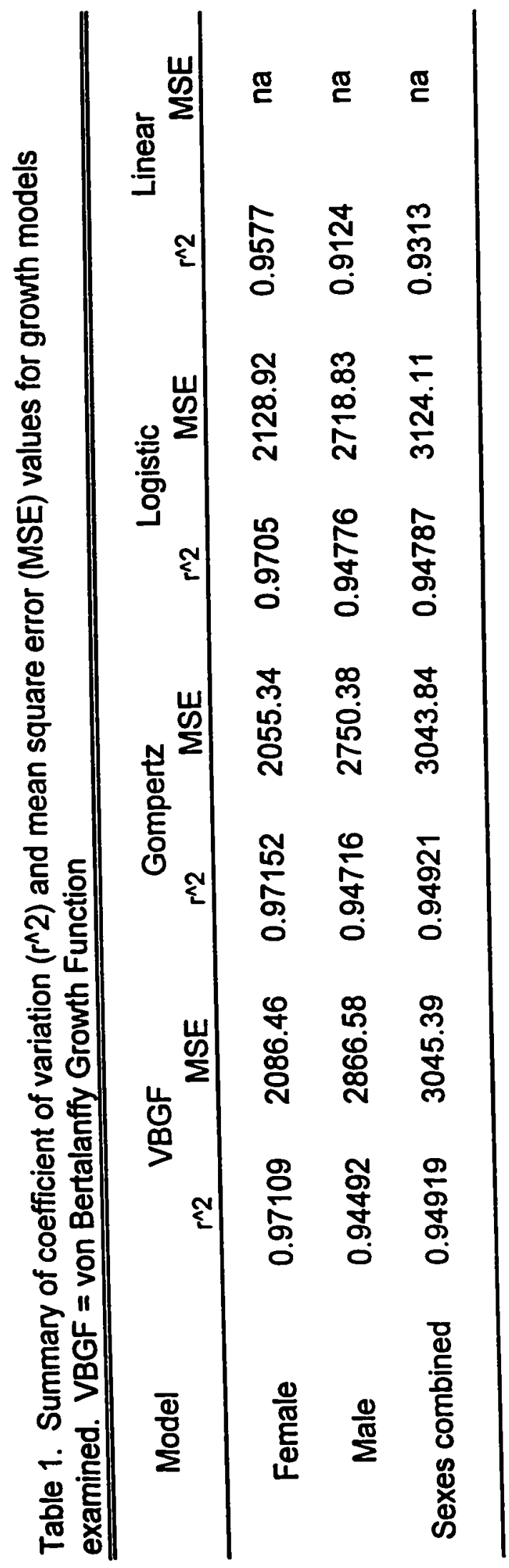




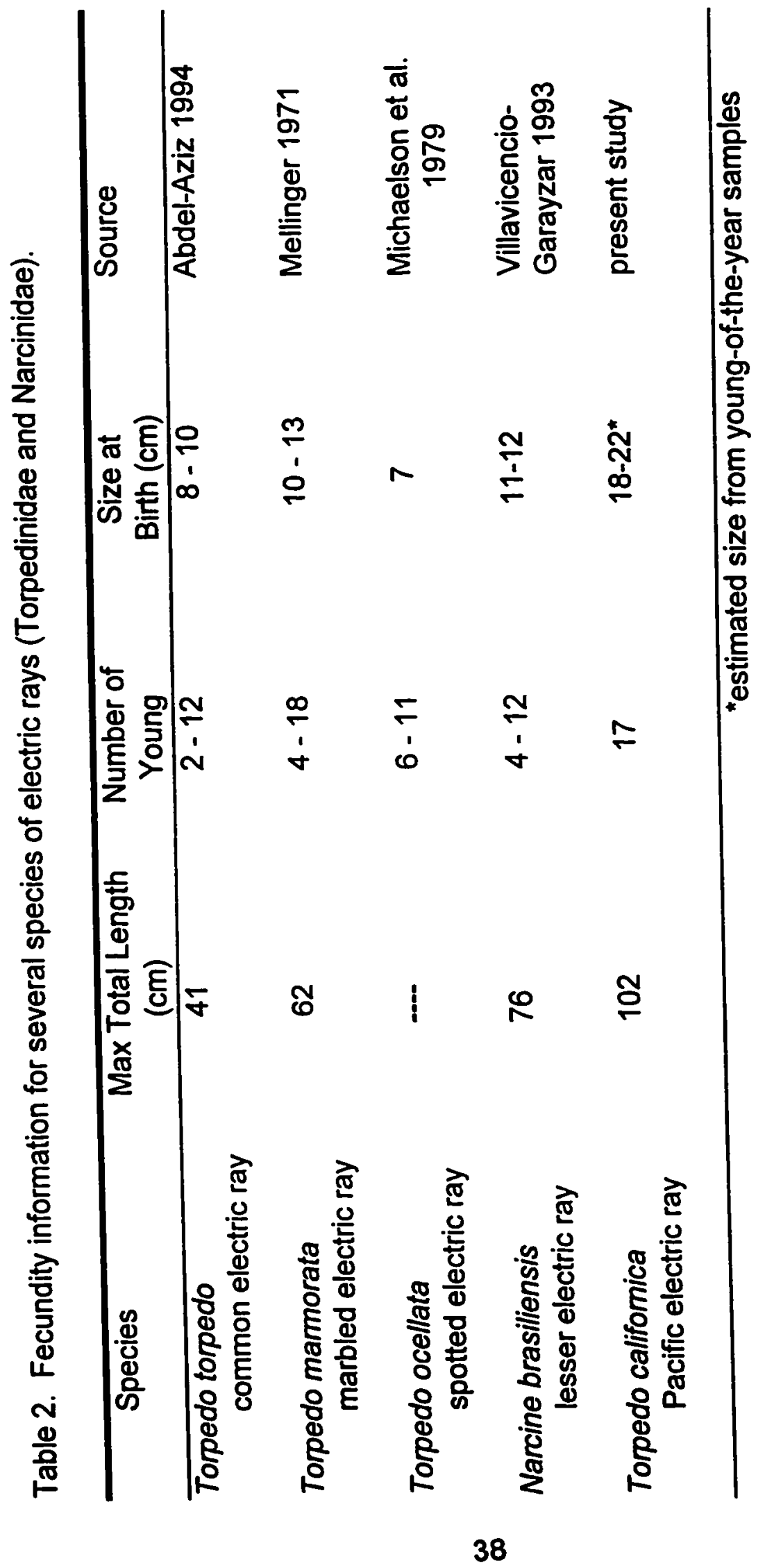














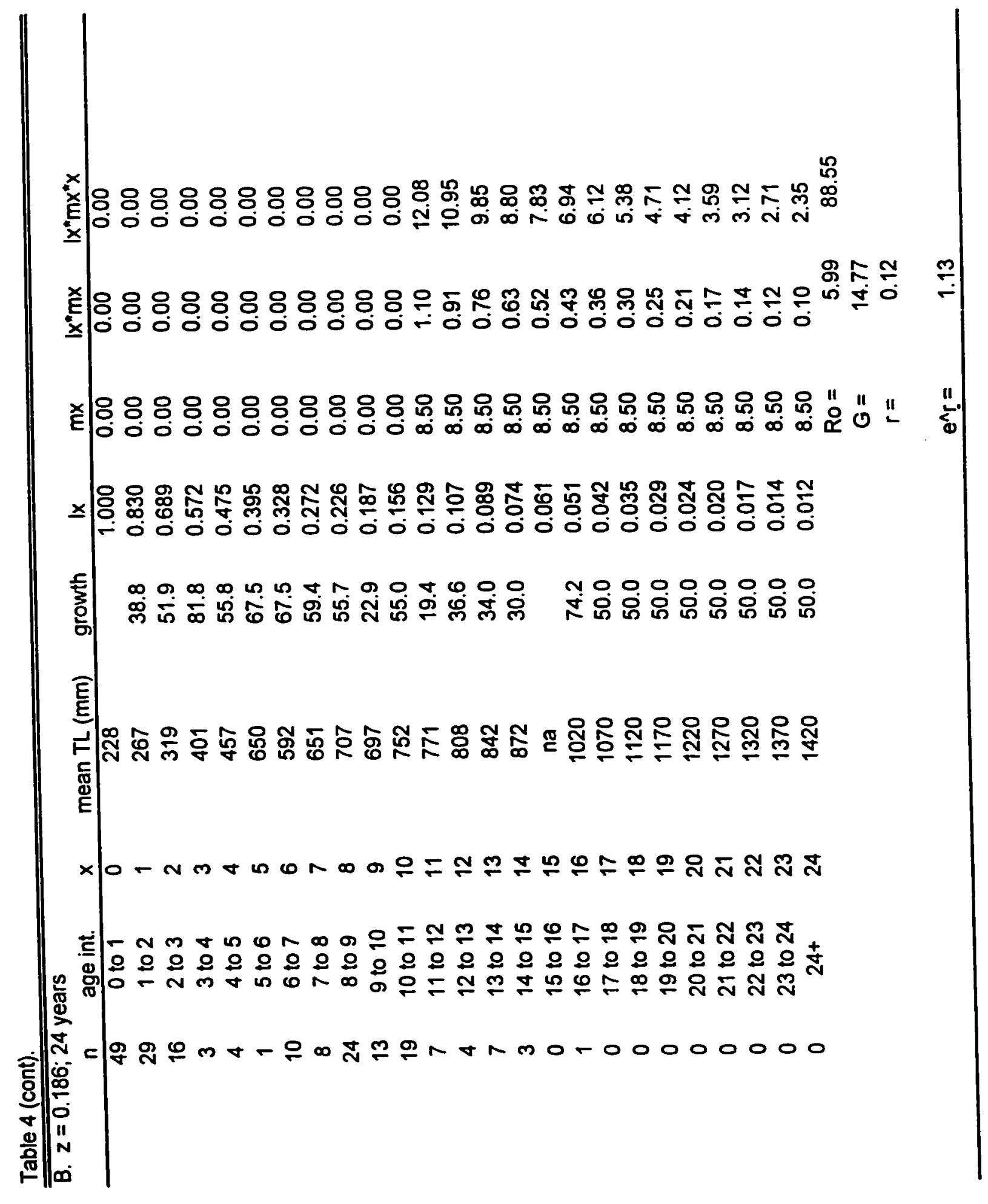




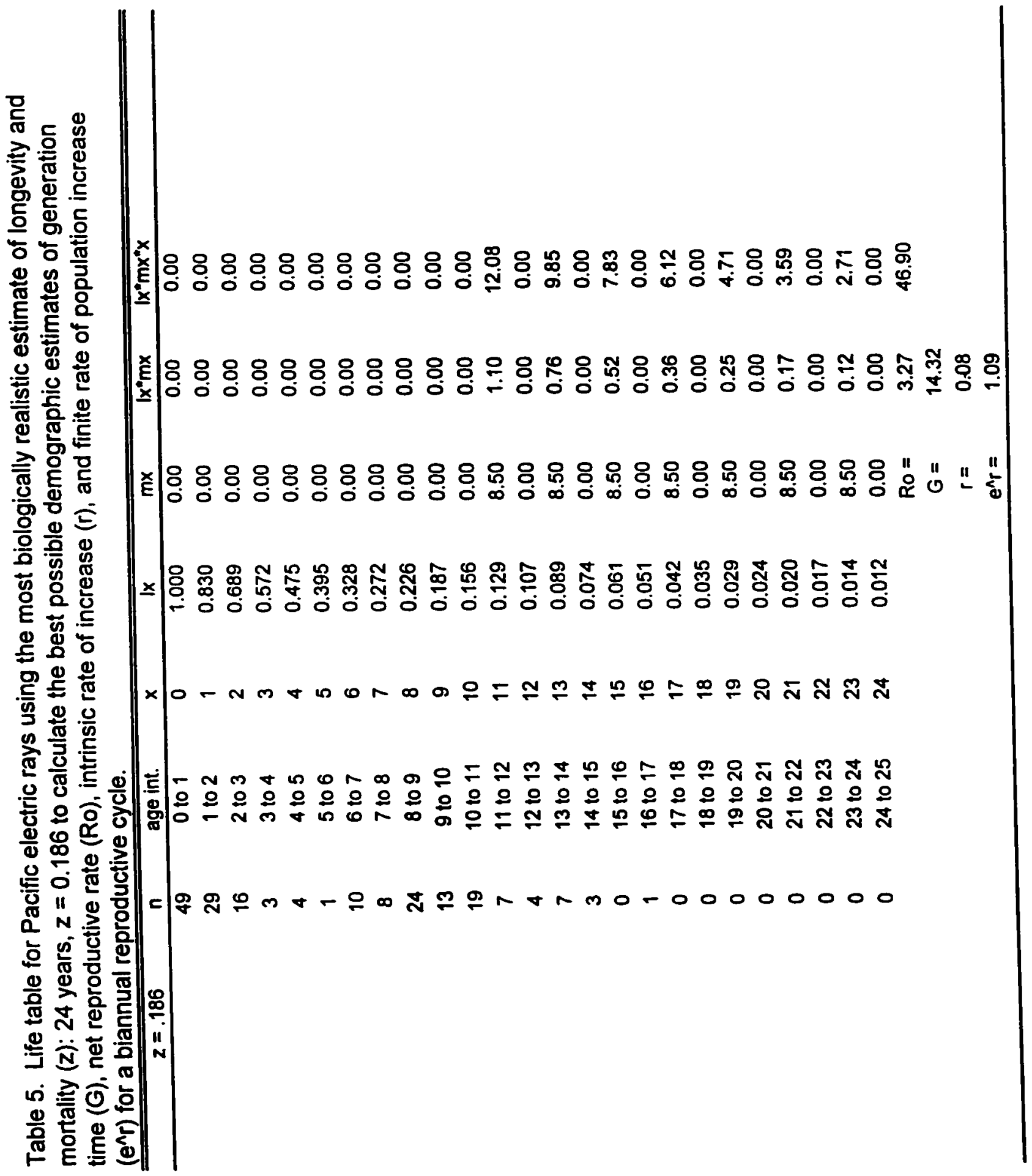




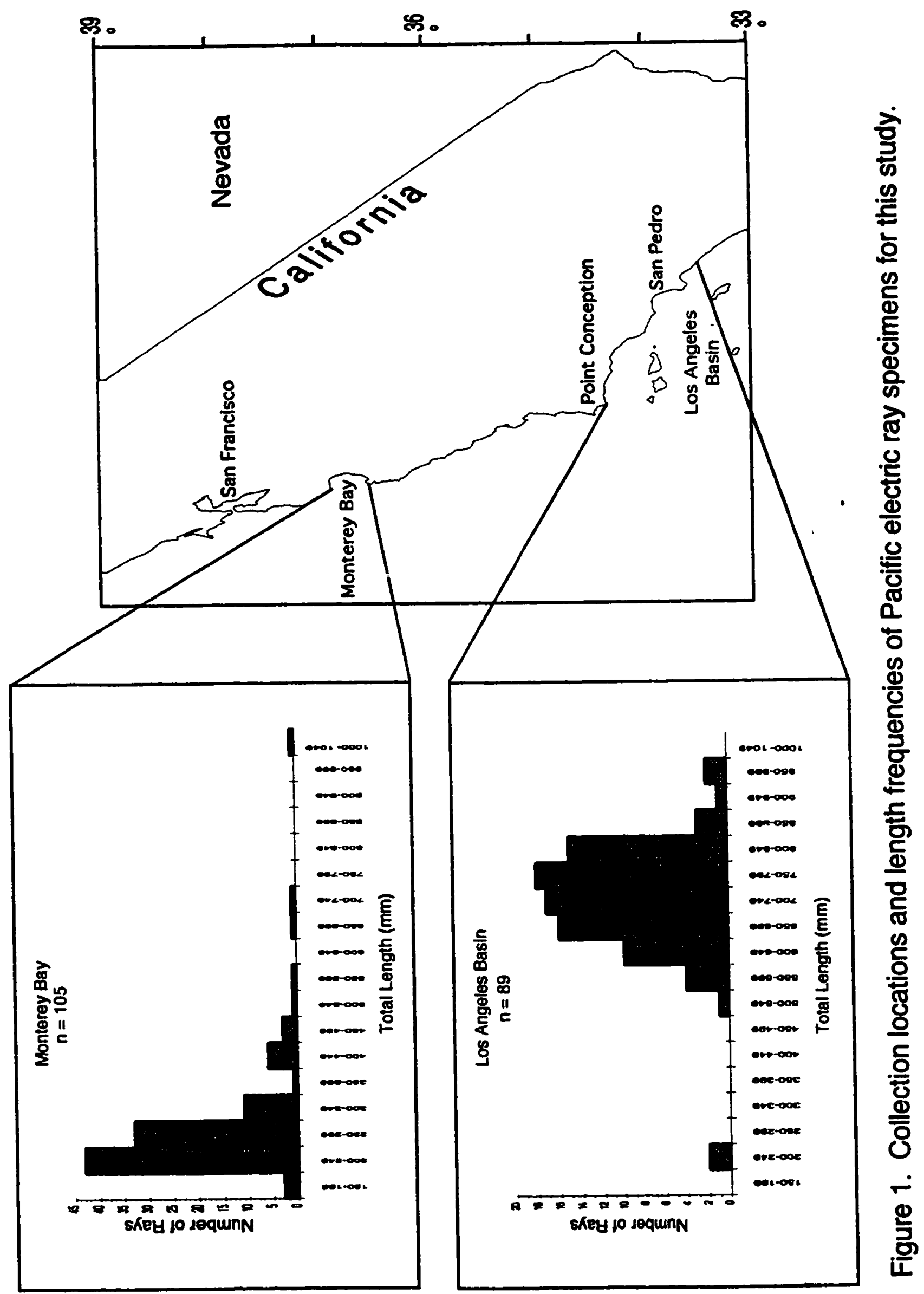



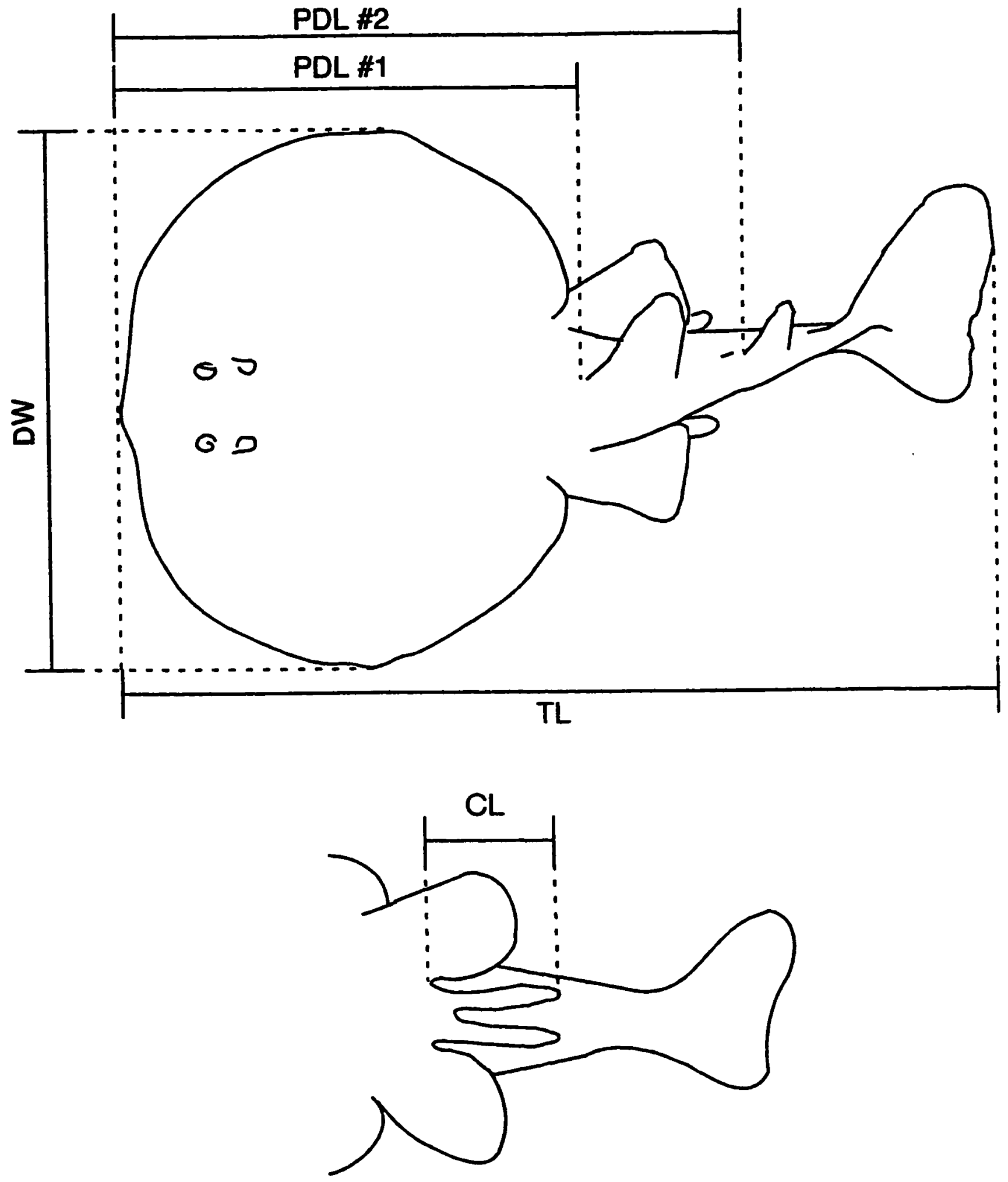

Figure 2. Linear measurements recorded for Pacific electric ray specimens. $\mathrm{TL}=$ total length; $\mathrm{DW}=$ disc width; $\mathrm{PDL} \# 1=$ predorsal 1; $\mathrm{PDL} \# 2=$ predorsal 2 ; and $\mathrm{CL}=$ clasper length. All measurements were in millimeters. 
a.

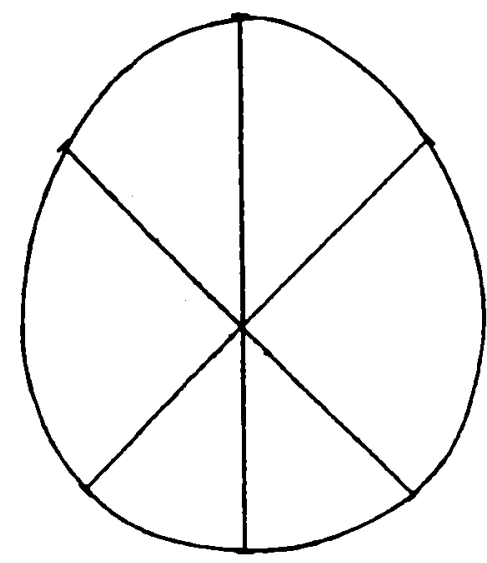

b.



Figure 3. Diagram of Pacific electric ray vertebrae. a) Centrum diameter measurements. b) Change in vertebral shape with size/age. 


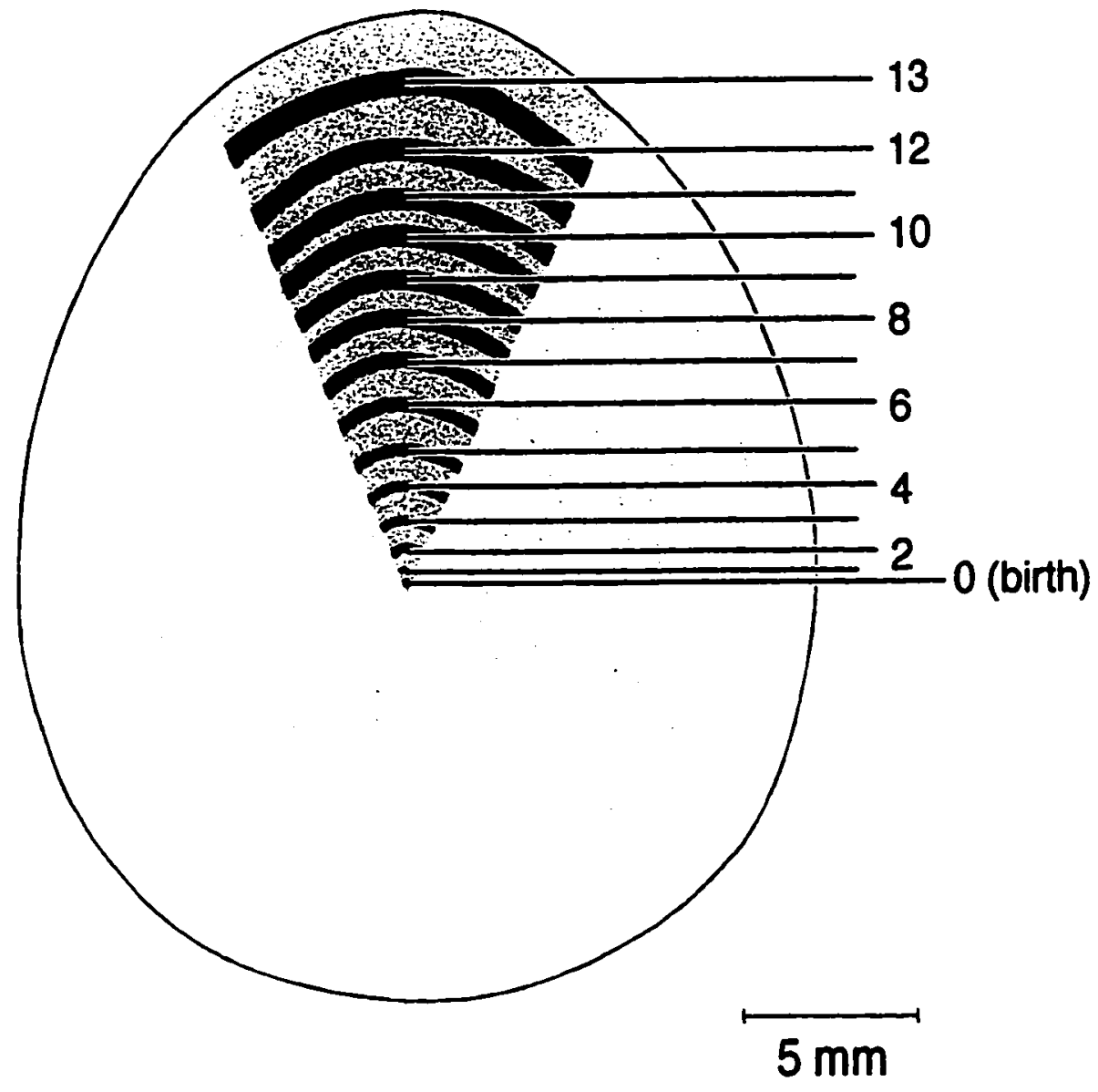

Figure 4. Illustration of Pacific electric ray vertebral face with lead microtopographic enhancement of the banding pattern. Numbers represent estimated years since birth. 


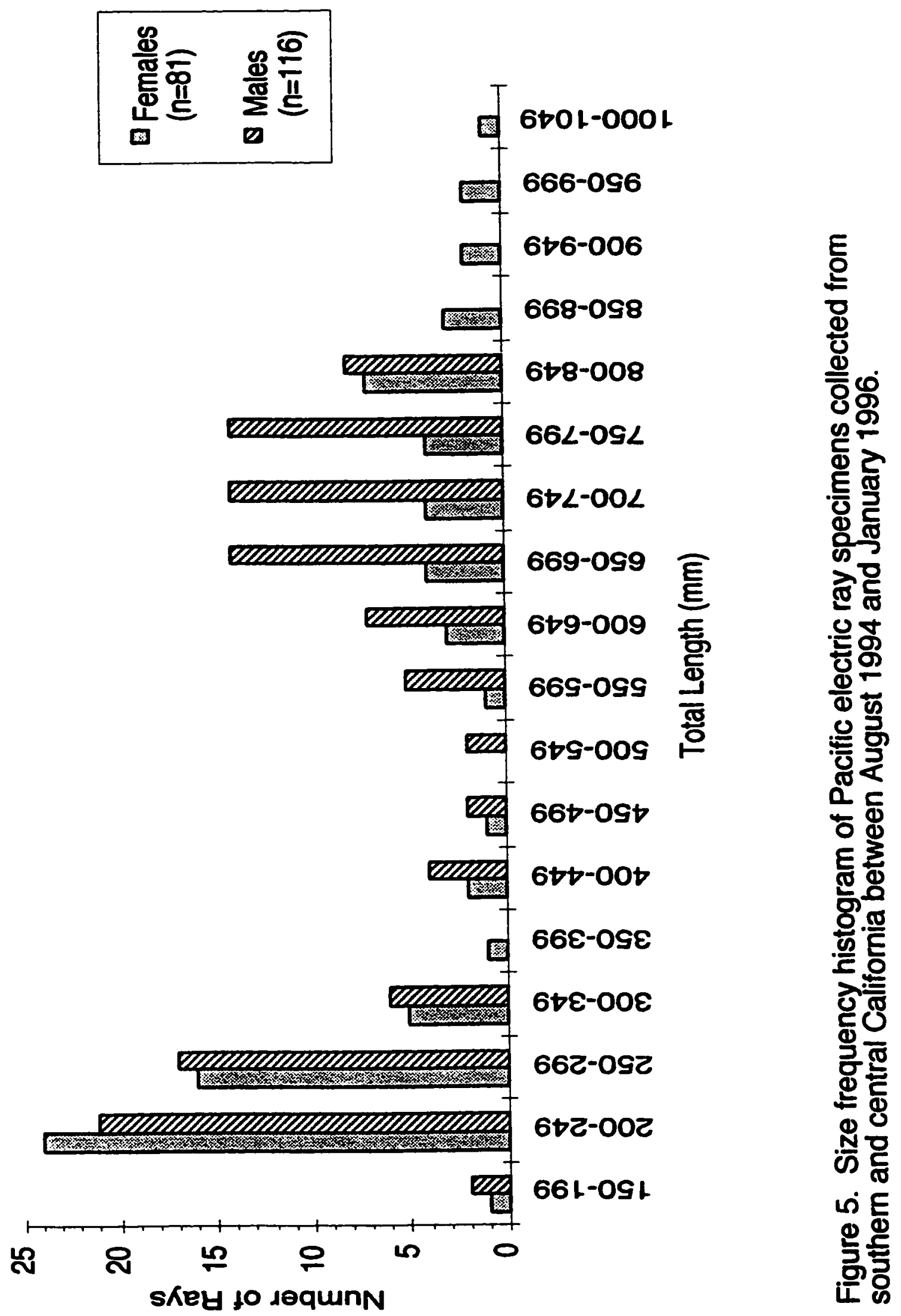


a.

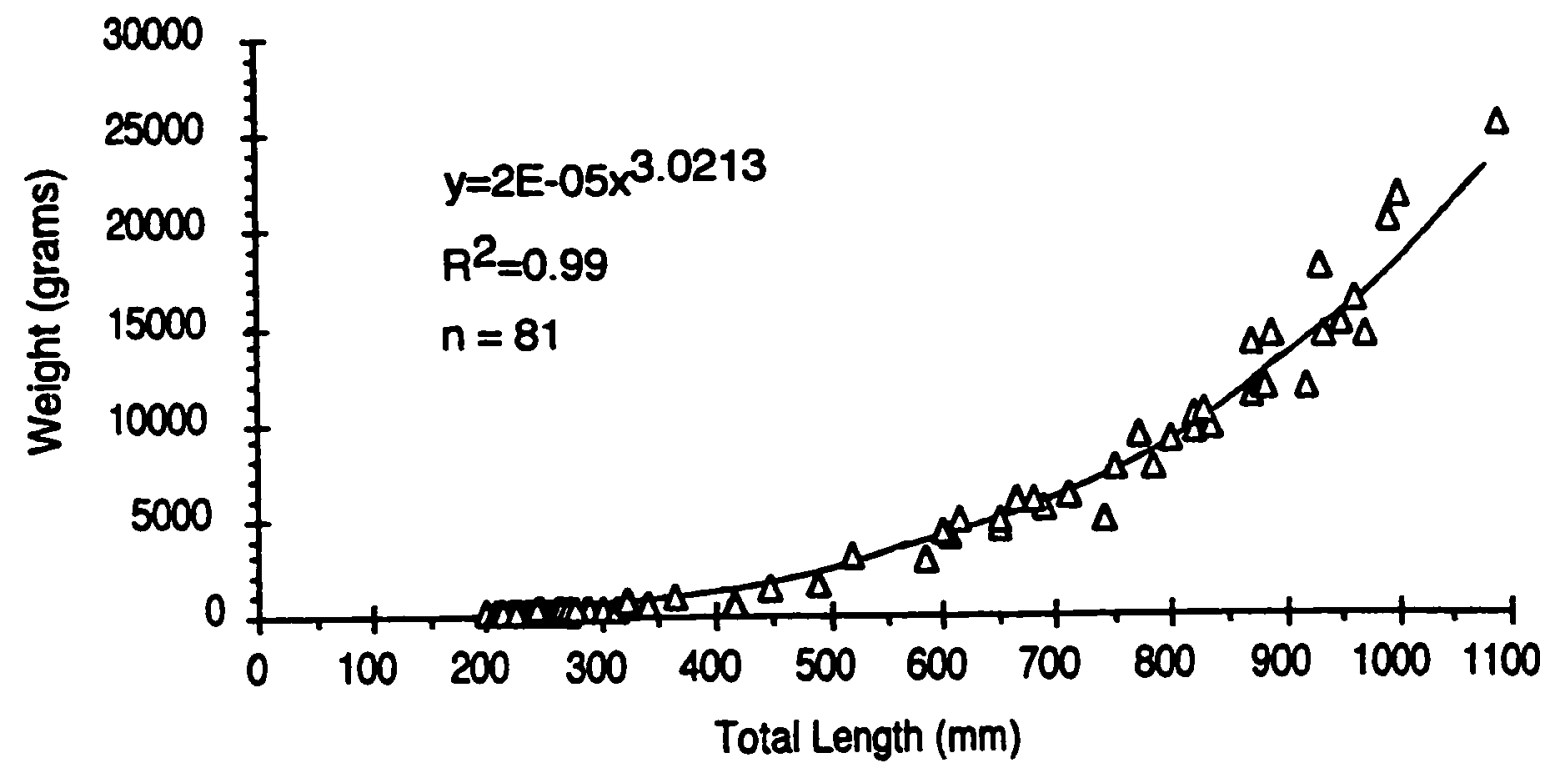

b.

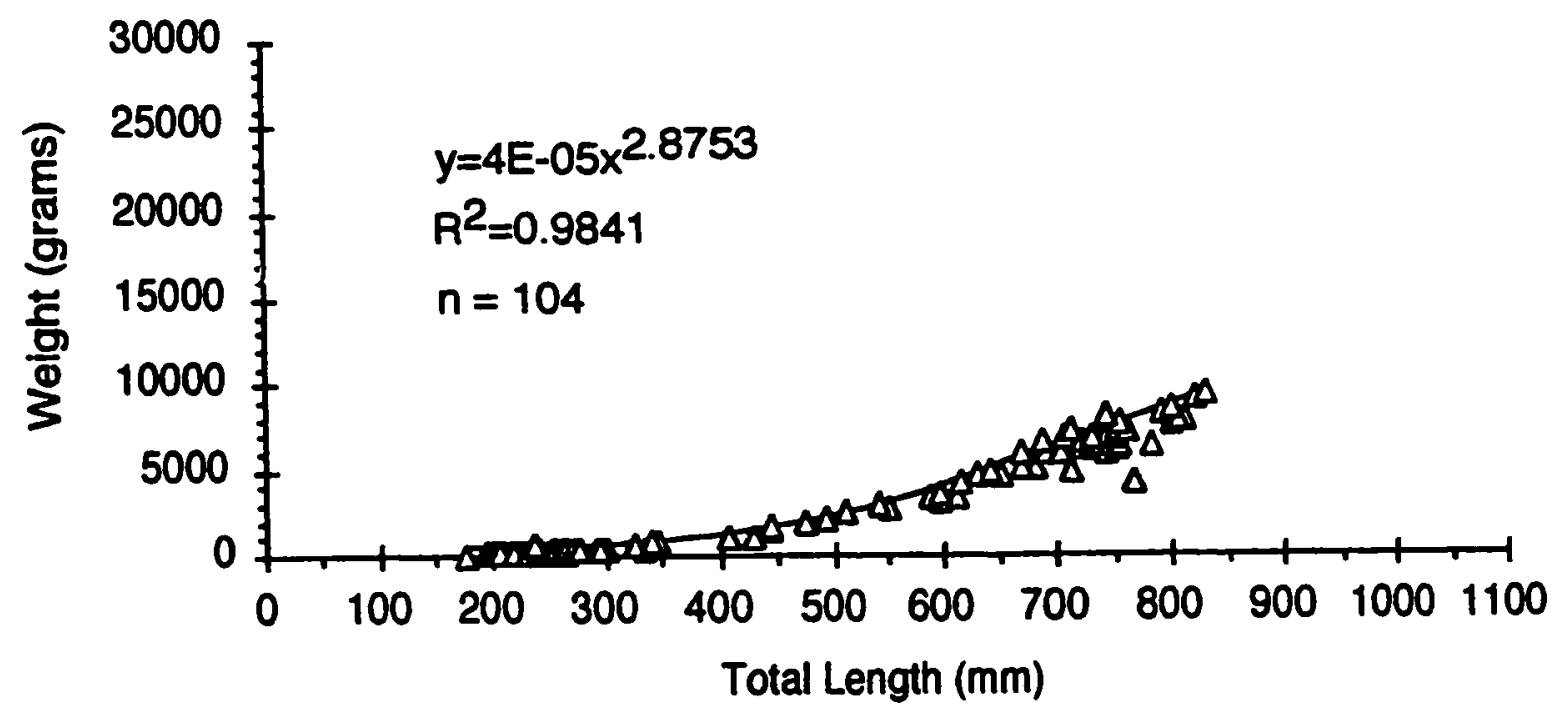

Figure 6. Total length - weight relationships for female (a) and male (b) Pacific electric rays. 




b.
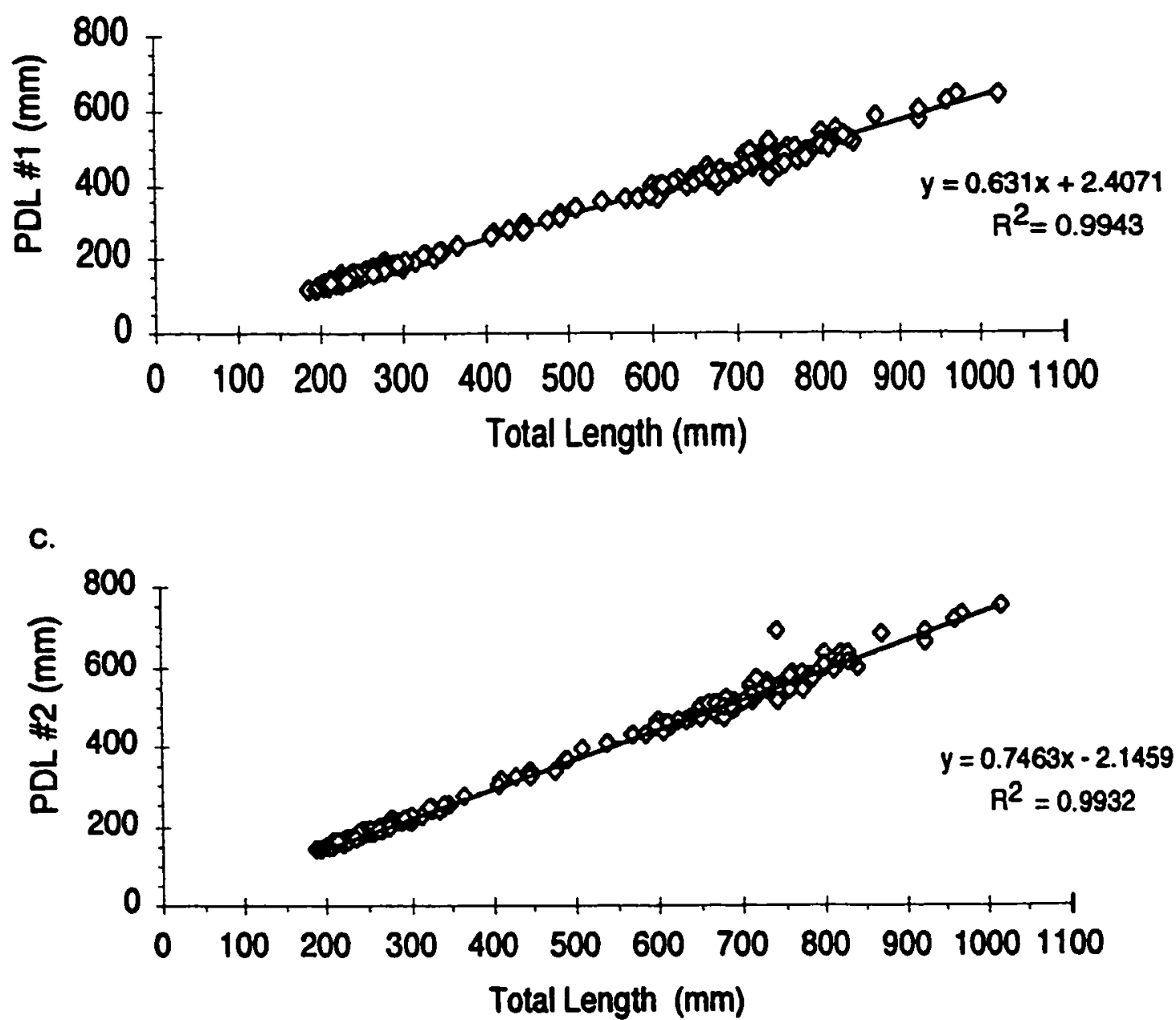

Figure 7. Total length relationships with disk width, first predorsal length (PDL \#1), and second predorsal length (PDL \#2) recorded for Pacific electric ray specimens. 


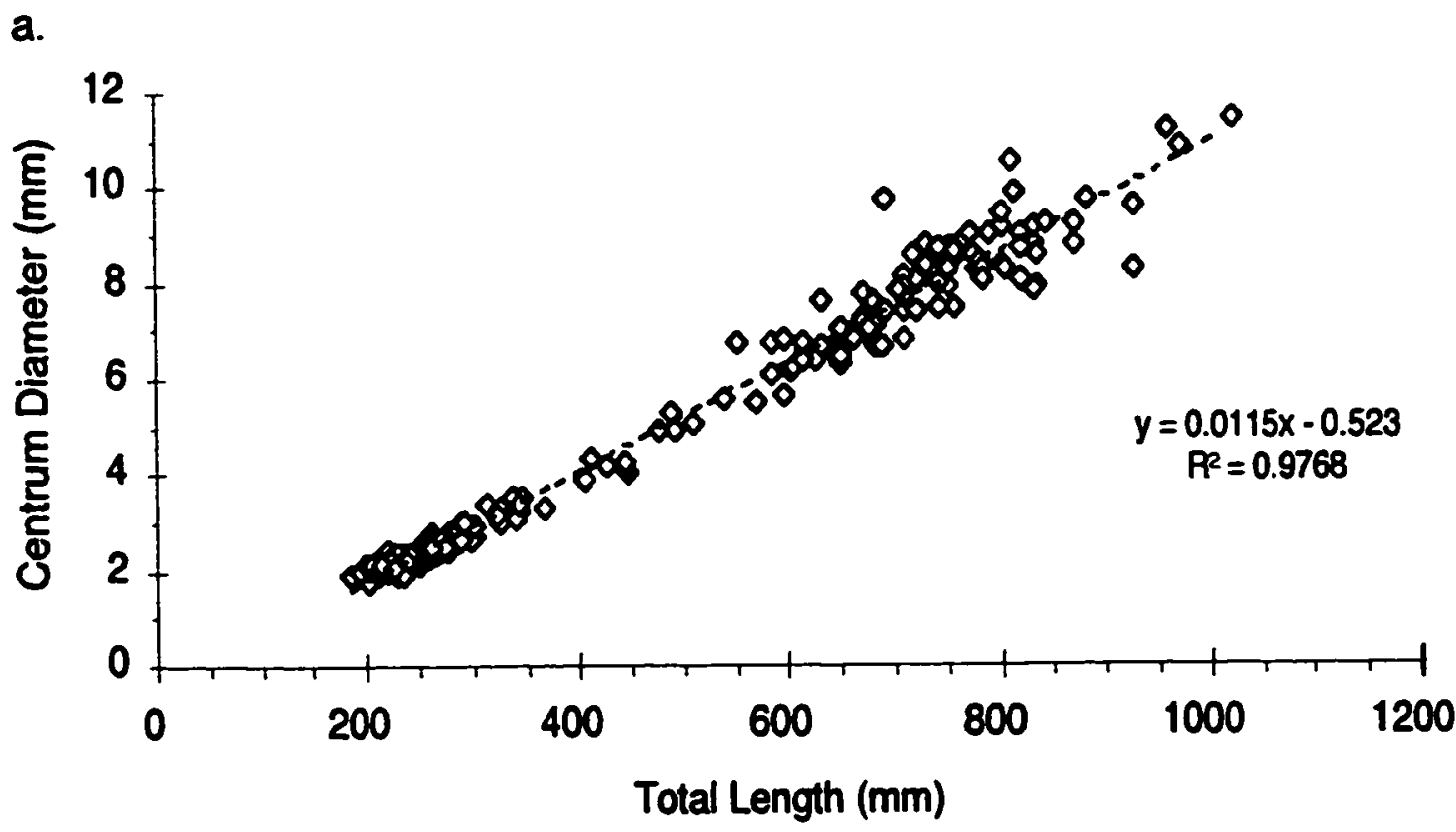

b.

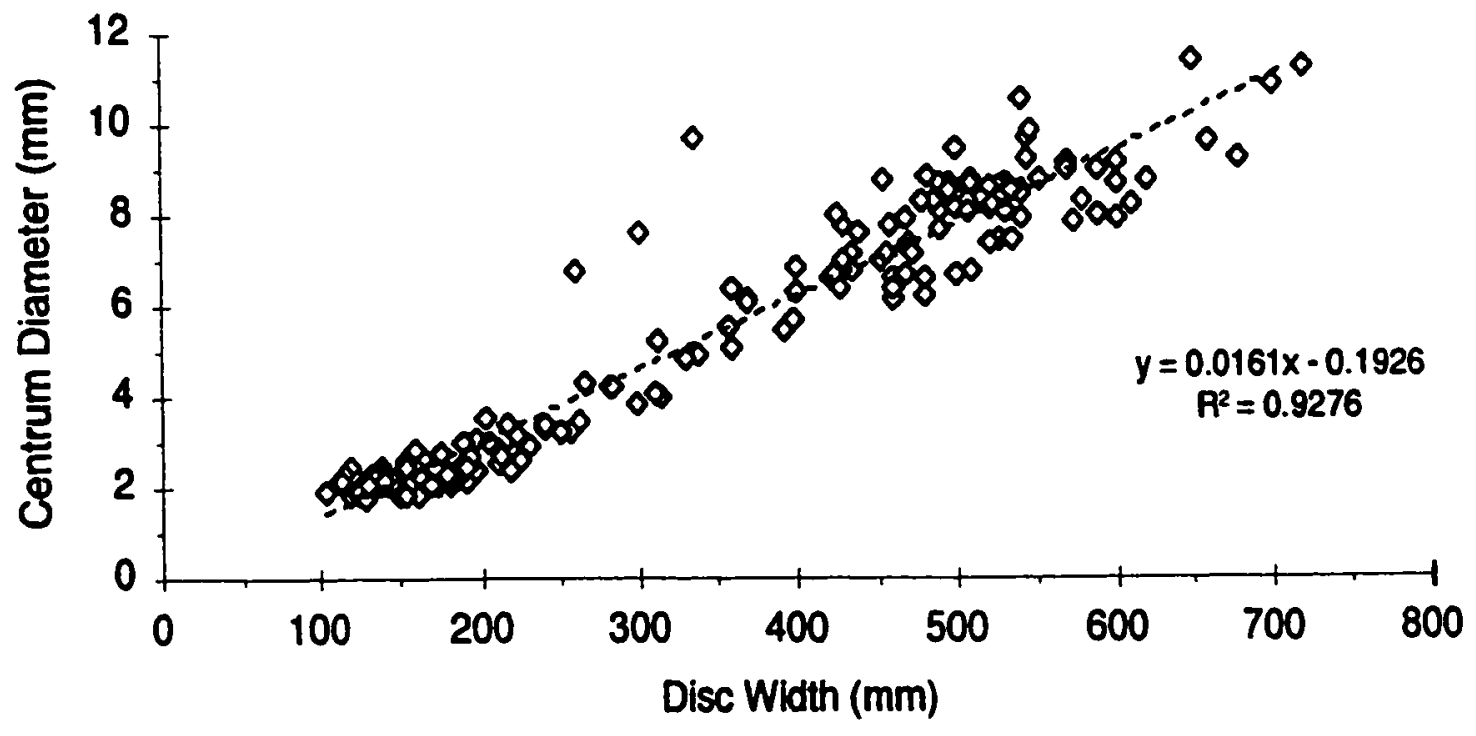

Figure 8. Total length (a) and disc width (b) versus centrum diameter. 

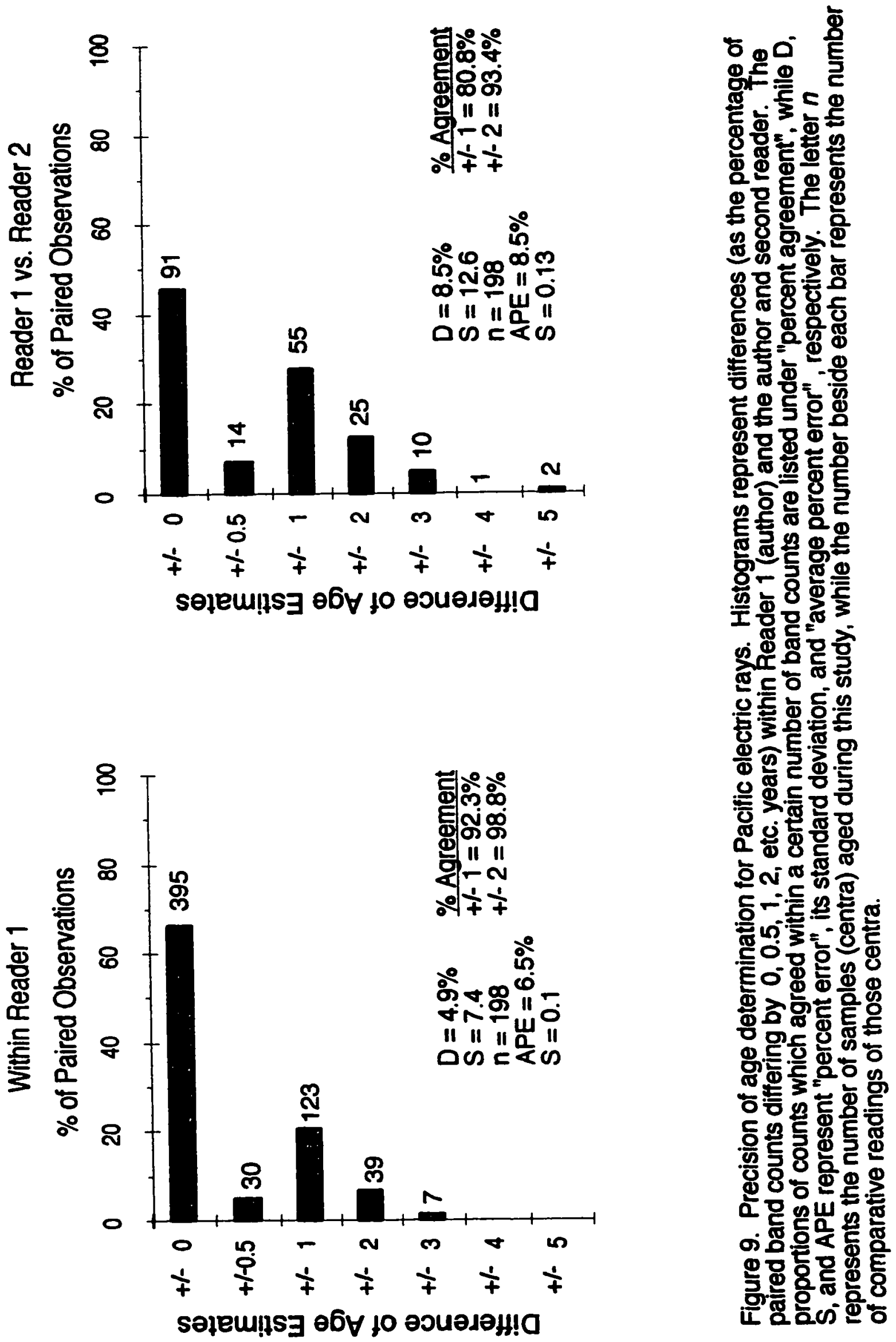


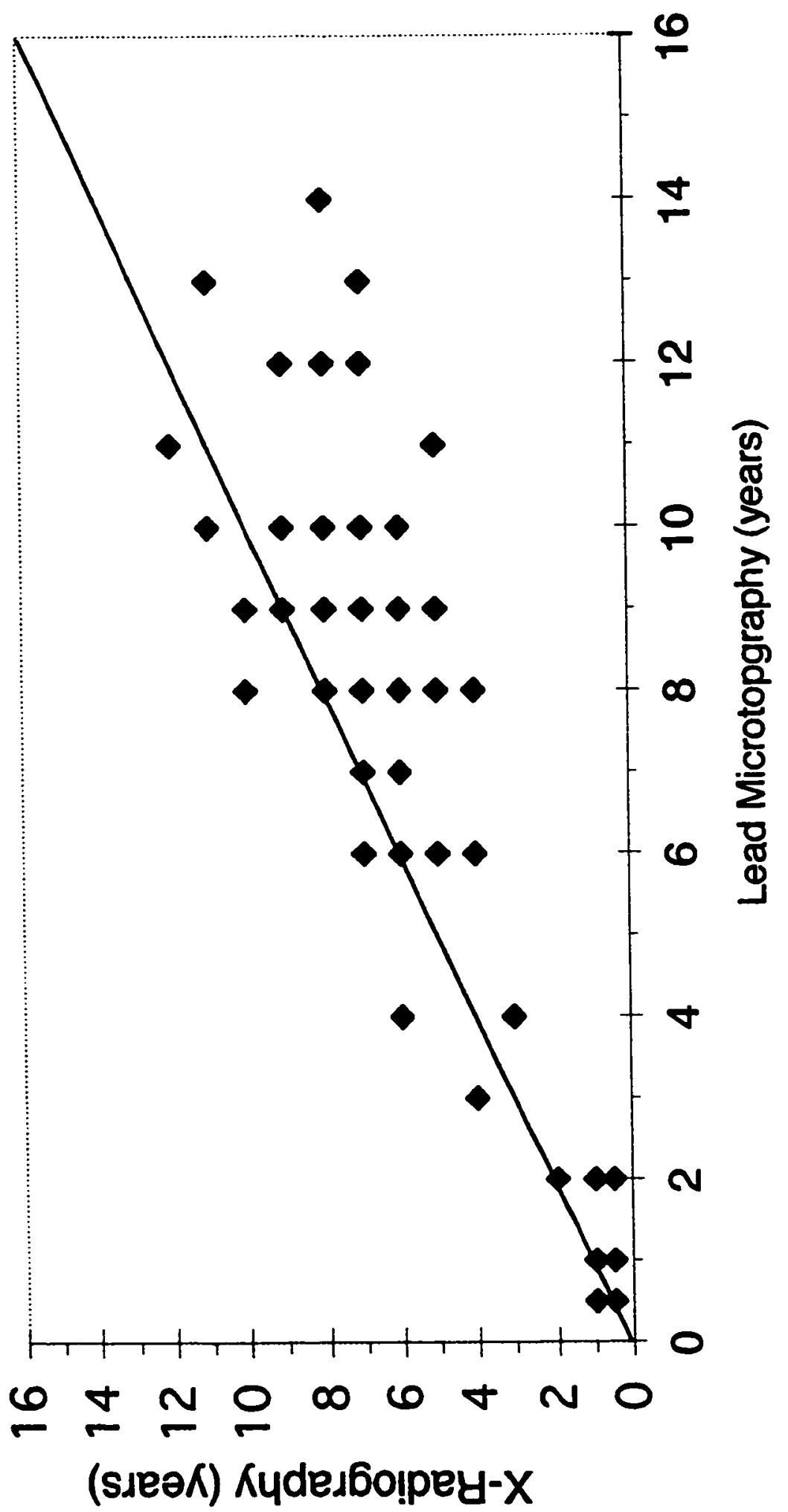




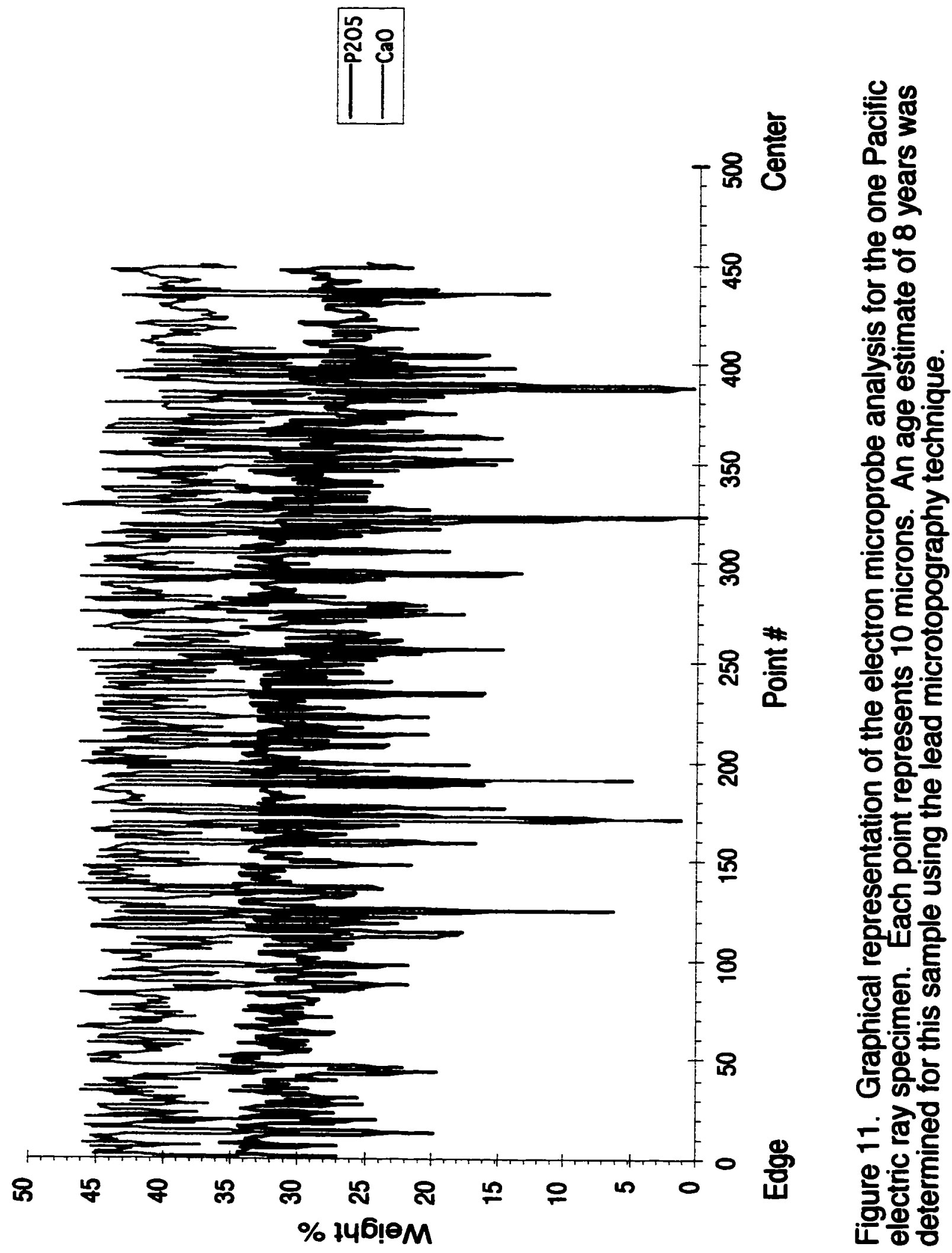




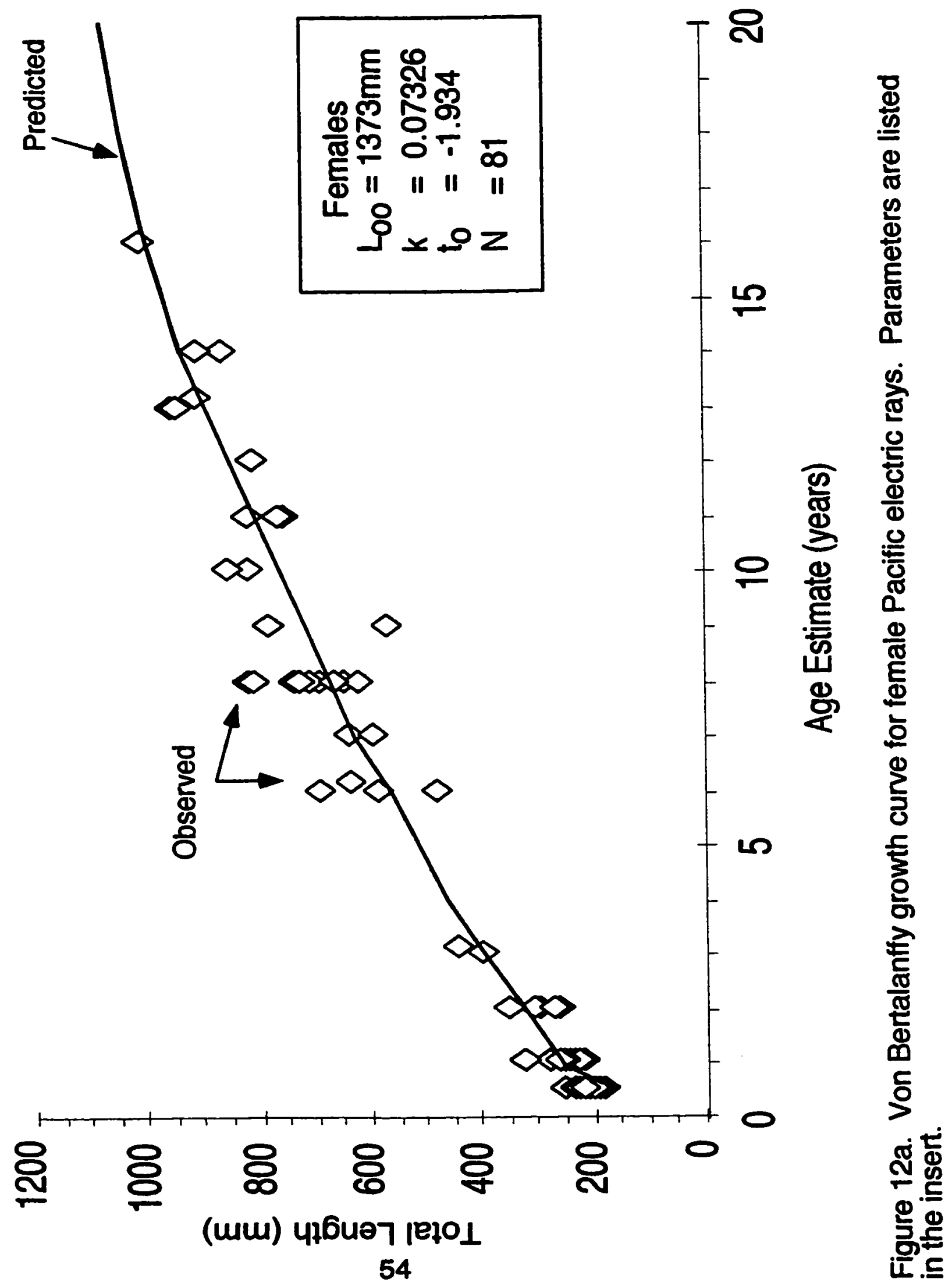




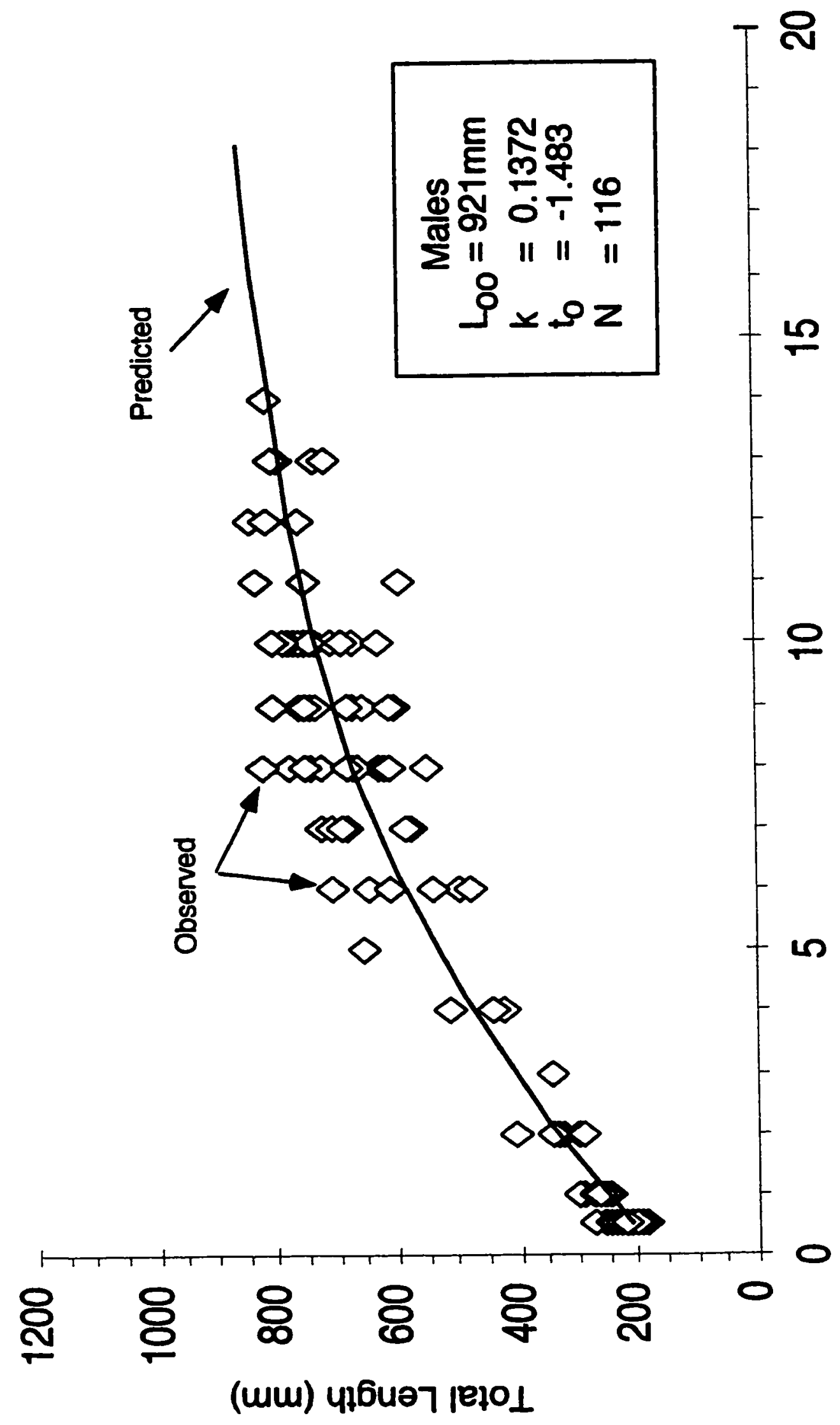




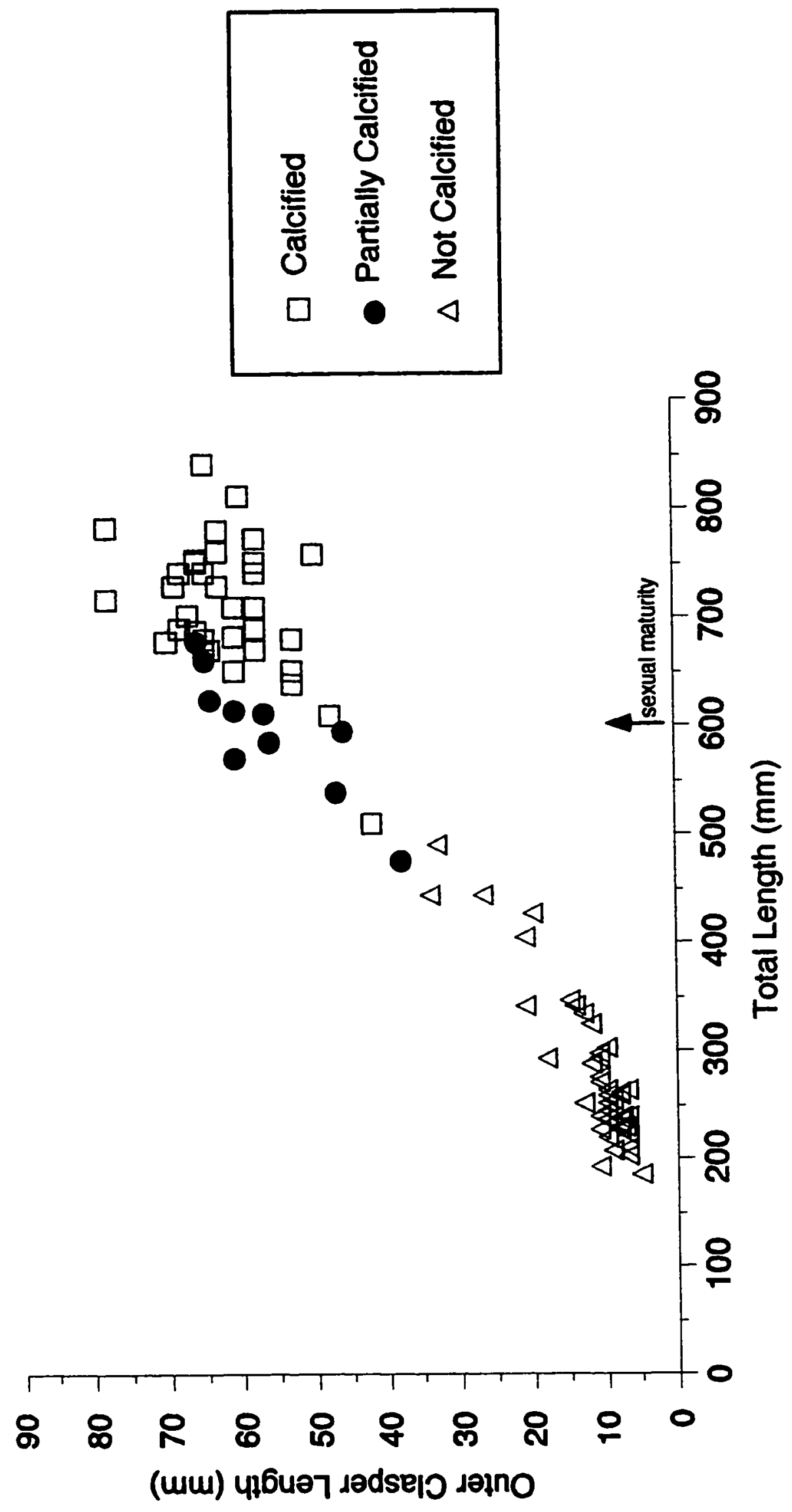

芧

तั

은

త్

o

을 틀

ณ 8

$\Phi$

$\leftarrow \infty$

을 궁

퉁ㅇㅇ

등

\$힝

을

它

닝

కॅ

ㅇํ

당

б

도은

중을

옹

능

을 잉

क

을 응

需

똥ํำ

ம்

응 응

온웡 












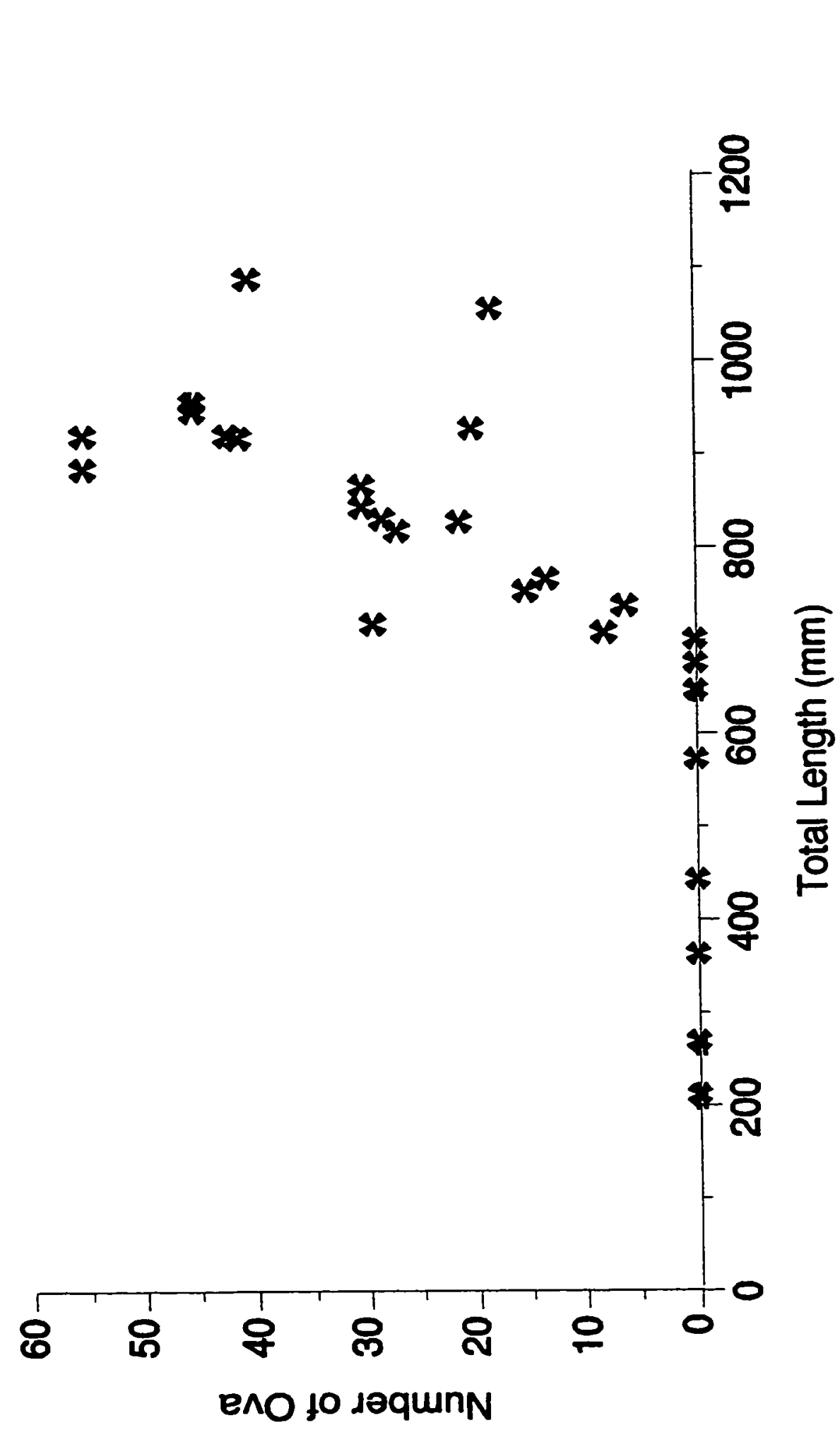

통ำ

ส

은 틍

$\therefore$

क्ष

iI

대트

s.돈

ส্웡ㅇํ

ơ

등

D.

ब के

응엉

엉

08

ㅎ․드

(⿻)

ठ웡

ธิ㇒

可

ఖ들

हᄃํ

ว ठ․

윽흥

둥엉

요

ఏ. 등

정응

옹이

ธ。

을



동.

家

몽

뜨워

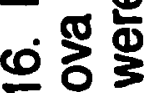

후으

운옳 틀 


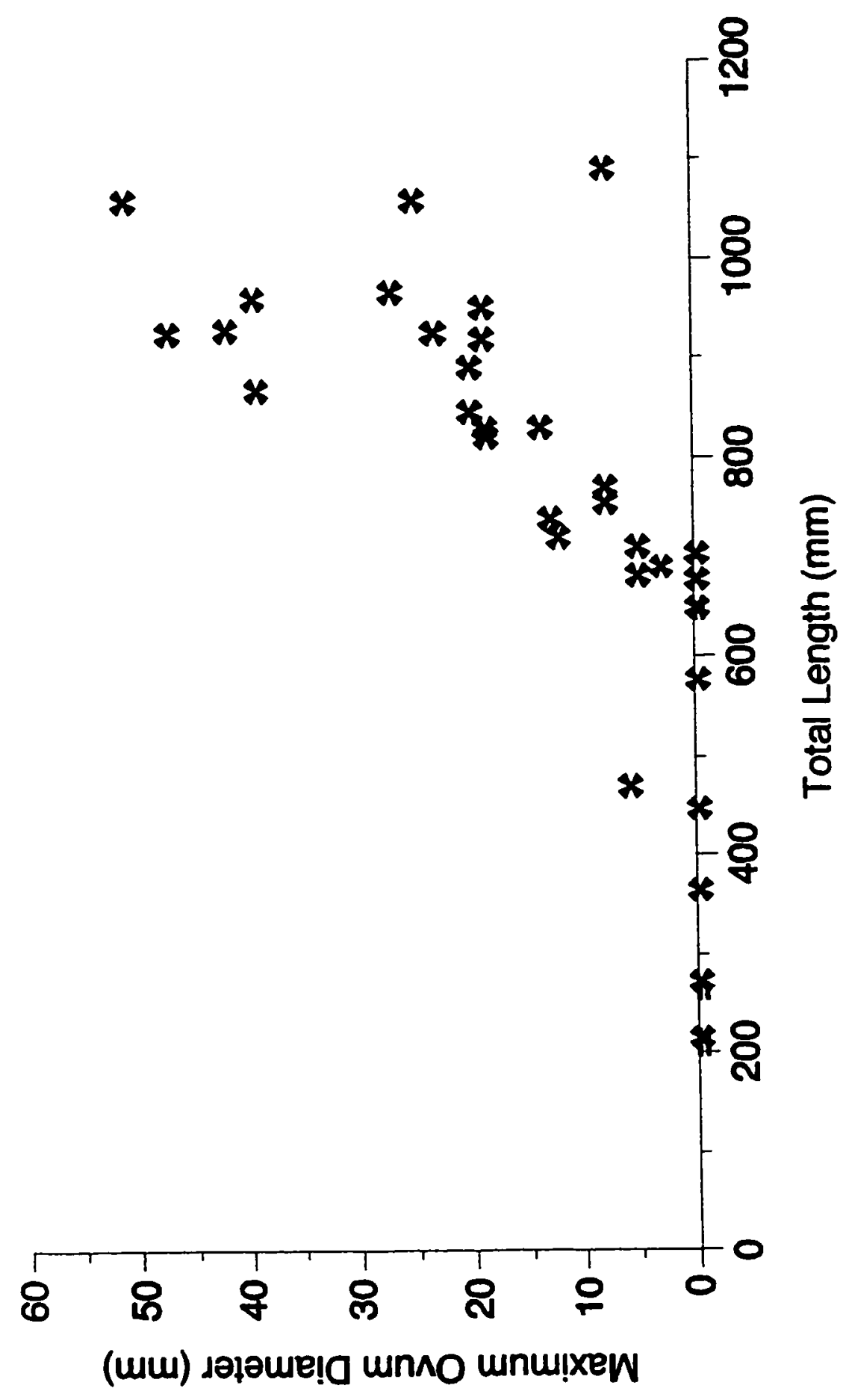

웅워

ธㅇํㅇ

II

동

สำ.으

을

흘

을

क

응

(⿻)

흠

可

$\Phi$

है

띃

톡 동

ㅇํำ

토음

등

E-

웅

두

옹이

Ф

징

올

오

을융

क늑

응

需

또

일

홍

政

훈형트 


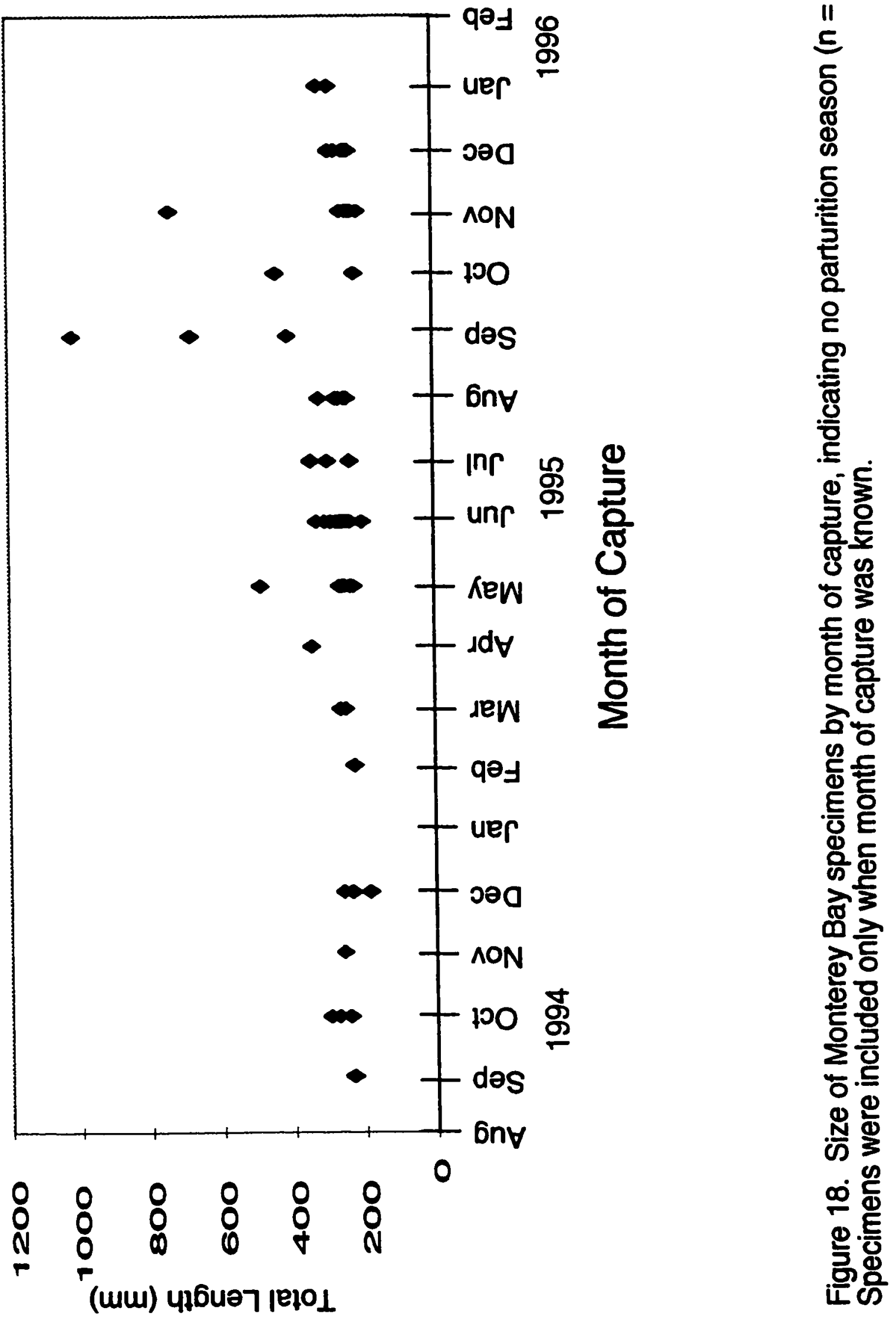



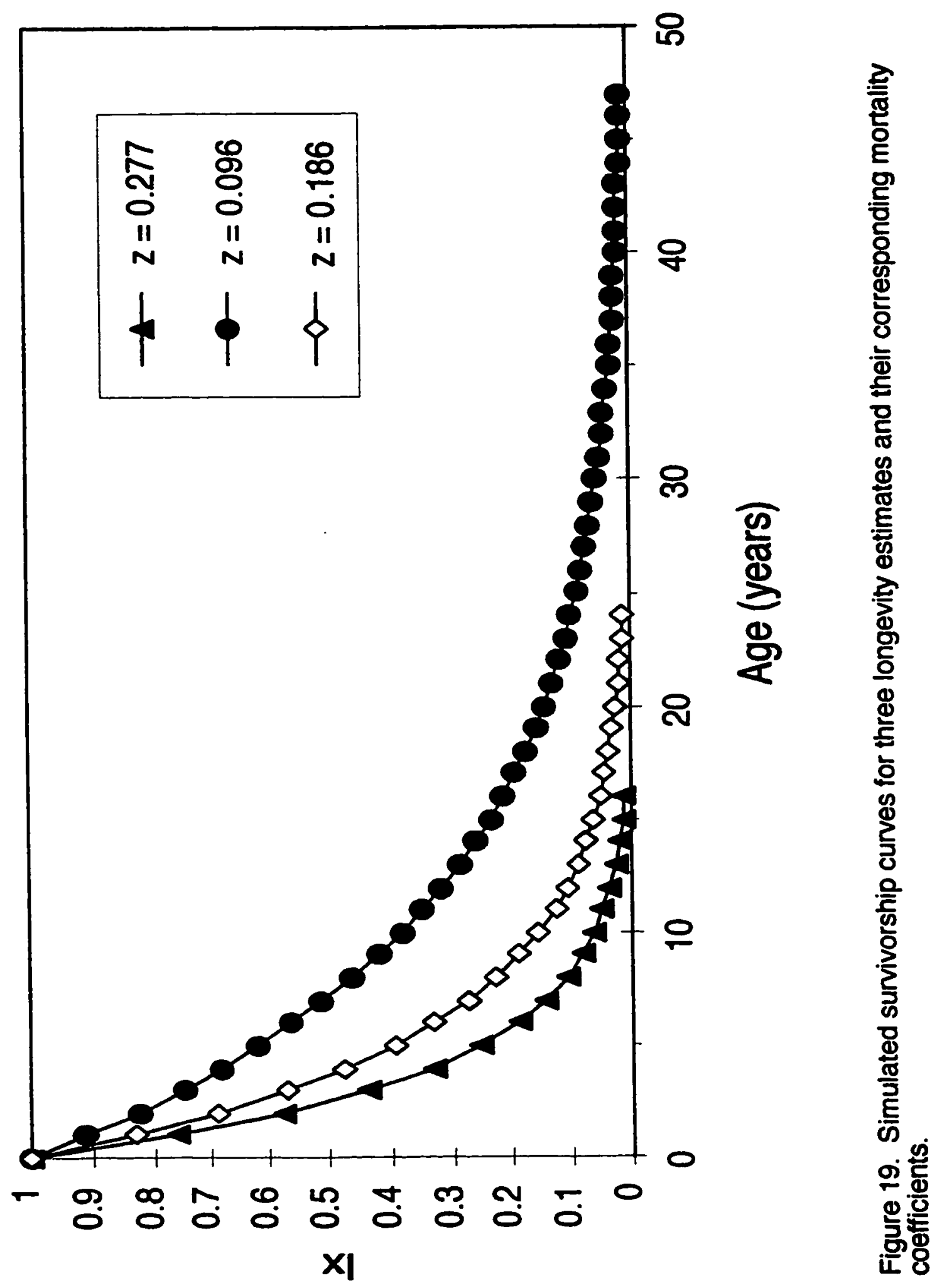

62 

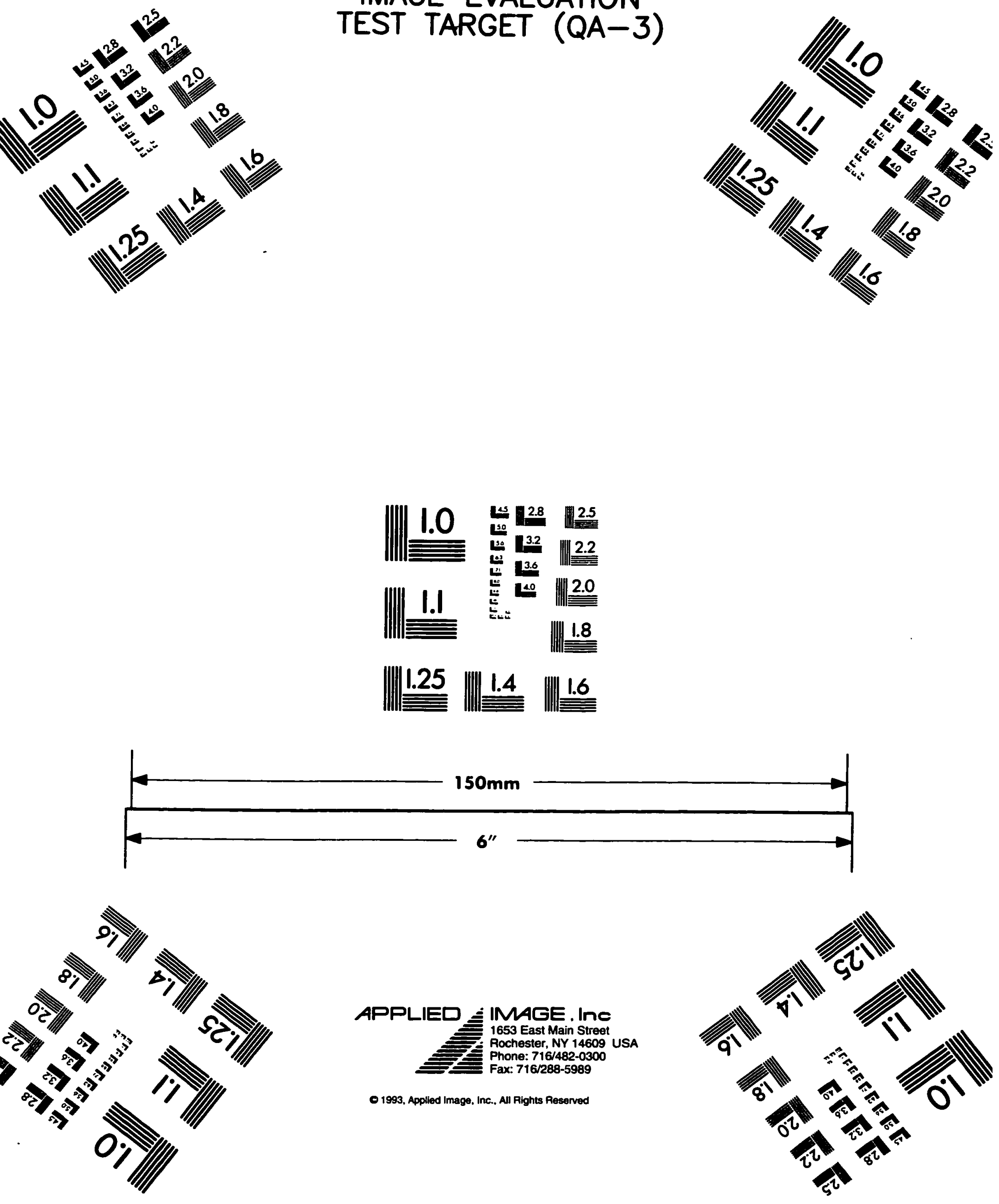